\title{
Expression of Prostaglandin E Synthases in Periodontitis
}

\author{
Immunolocalization and Cellular Regulation
}

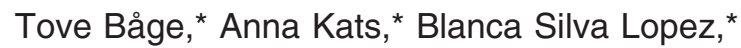
Gareth Morgan, ${ }^{\dagger}$ Gunnar Nilsson, ${ }^{\ddagger}$ Idil Burt, ${ }^{\S}$

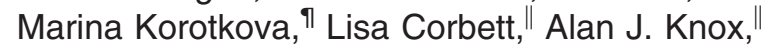
Leonardo Pino, ** Per-Johan Jakobsson," Thomas Modéer, ${ }^{*}$ and Tülay Yucel-Lindberg* From the Division of Pediatric Dentistry,* Department of Medicine, the Division of Pathology, Department of Laboratory Medicine, the Clinical Immunology and Allergy Unit, ${ }^{*}$ and the Rheumatology Unit, " Karolinska Institutet, Stockholm, Sweden; the Department of Orthodontics, ${ }^{\circledR}$ Eastman Institute, Stockholm, Sweden; the Division of Respiratory Medicine," City Hospital, University of Nottingham, Nottingham, United Kingdom; and the Örebro City Council, Postgraduate Dental Education Center,** Örebro, Sweden

The inflammatory mediator prostaglandin $\mathrm{E}_{2}\left(\mathrm{PGE}_{2}\right)$ is implicated in the pathogenesis of chronic inflammatory diseases including periodontitis; it is synthesized by cyclooxygenases (COX) and the prostaglandin $\mathrm{E}$ synthases MPGES-1, MPGES-2, and CPGES. The distribution of PGES in gingival tissue of patients with periodontitis and the contribution of these enzymes to inflammationinduced $\mathrm{PGE}_{2}$ synthesis in different cell types was investigated. In gingival biopsies, positive staining for PGES was observed in fibroblasts and endothelial, smooth muscle, epithelial, and immune cells. To further explore the contribution of PGES to inflammation-induced PGE $_{2}$ production, in vitro cell culture experiments were performed using fibroblasts and endothelial, smooth muscle, and mast cells. All cell types expressed PGES and COX-2, resulting in basal levels of $\mathrm{PGE}_{2}$ synthesis. In response to tumor necrosis factor (TNF- $\alpha$ ), IL-1 $\beta$, and cocultured lymphocytes, however, mPGES-1 and COX-2 protein expression increased in fibroblasts and smooth muscle cells, accompanied by increased $\mathrm{PGE}_{2}$, whereas mPGES-2 and cPGES were unaffected. In endothelial cells, TNF- $\alpha$ increased PGE 2 production only via COX-2 expression, whereas in mast cells the cytokines did not affect $\mathrm{PGE}_{2}$ enzyme expression or $\mathrm{PGE}_{2}$ production. Furthermore, $\mathbf{P G E}_{2}$ production was diminished in gingival fibroblasts derived from mPGES-1 knockout mice, compared with wild-type fibroblasts. These results suggest that fibroblasts and smooth muscle cells are important sources of mPGES-1, which may contribute to in- creased $\mathrm{PGE}_{2}$ production in the inflammatory condition periodontitis. (Am J Pathol 2011, 178:1676-1688; DOI: 10.1016/j.ajpath.2010.12.048)

Periodontitis is a chronic inflammatory disease involving interactions among bacterial products, host cells, and inflammatory mediators. The inflammatory response results in destruction of the tissue and alveolar bone supporting the teeth and can ultimately lead to tooth loss. ${ }^{1}$ The inflammatory mediator prostaglandin $\mathrm{E}_{2}\left(\mathrm{PGE}_{2}\right)$ has been identified as a potent mediator in the pathogenesis of periodontitis. Levels of $\mathrm{PGE}_{2}$ are elevated in the gingival tissue and gingival fluid of patients with periodontitis, compared with periodontally healthy subjects. ${ }^{2-5}$ It has also been reported that the inhibition of $\mathrm{PGE}_{2}$ using selective or nonselective nonsteroidal anti-inflammatory drugs decreases periodontal disease progression and reduces alveolar bone resorption, which highlights the significance of $\mathrm{PGE}_{2}$ in the pathogenesis of periodontal disease..$^{6-8}$ In addition to these findings, bone resorption in lipopolysaccharide-treated mice has been shown to be dependent on $\mathrm{PGE}_{2}$ synthesis, a finding that might be explained by the observation that $\mathrm{PGE}_{2}$ stimulates the formation of osteoclasts. ${ }^{9,10}$

Prostaglandin $E_{2}$ is produced via three different groups of enzymes, acting sequentially. The first group of enzymes, phospholipase $A_{2}$, converts membrane lipids to arachidonic acid. ${ }^{11,12}$ The second group of isoenzymes, cyclooxygenases (COX-1 and COX-2) convert arachidonic acid to prostaglandin $\mathrm{H}_{2}{ }^{13}$ Finally, the third and most recently identified group of isoenzymes, the prostaglandin $\mathrm{E}$ synthases (PGE synthases) catalyze the conversion of COX-derived prostaglandin $\mathrm{H}_{2}$ to $\mathrm{PGE}_{2}$ in the final step of $\mathrm{PGE}_{2}$ biosynthesis. ${ }^{14,15}$ Three distinct PGE synthase isoenzymes have been characterized, and research is ongoing to further define the roles of these enzymes in different

Supported by grants from the Swedish Research Council, project no. 73XD-15005, the Swedish Patent Revenue Fund, the Swedish Dental Society, and the Karolinska Institute.

T.B. and A.K. contributed equally to the present work.

Accepted for publication December 22, 2010.

Address reprint requests to Tülay Yucel-Lindberg, Ph.D., Department of Dental Medicine, Karolinska Institute, Box 4064, SE-14104 Huddinge, Sweden. E-mail: tulay.lindberg@ki.se. 
chronic inflammatory conditions, especially in light of the discovery of the adverse effects of COX-2 inhibitors. ${ }^{16-19}$ The microsomal membrane-associated and glutathione-dependent PGE synthase (mPGES-1) is induced by pro-inflammatory stimuli and involved in delayed $\mathrm{PGE}_{2}$ synthesis. ${ }^{14,17,20}$ The cytosolic PGE synthase (CPGES) is reported to be involved in the immediate release of $\mathrm{PGE}_{2},{ }^{21}$ and the glutathione-independent mPGES-2 has been reported to contribute to immediate and delayed $\mathrm{PGE}_{2}$ synthesis but is not essential for $\mathrm{PGE}_{2}$ synthesis. ${ }^{22-24}$

The enhanced biosynthesis and role of $\mathrm{PGE}_{2}$ in periodontal tissue have been well established, although there are currently no data about the expression of the three PGE synthases in periodontitis. Furthermore, there are no reports addressing the contribution of the different cells in the connective tissue to $\mathrm{PGE}_{2}$ production. In one study, however, Siegel et al ${ }^{25}$ demonstrated the expression of mPGES-1 in gingival tissue of periodontally healthy subjects and in experimental gingivitis.

In contrast to the PGE synthases, the upstream enzyme COX-2 has been relatively widely studied. It has been reported that COX-2 expression is up-regulated in inflamed periodontal tissue, as well as in gingival tissue from subjects with chronic periodontitis, compared with gingival tissue obtained from healthy subjects. ${ }^{26-28}$

In light of the lack of information on PGE synthases in periodontal tissue, the aim of the present study was to investigate the cellular localization of $\mathrm{PGE}_{2}$-producing enzymes, focusing on the expression of PGE synthases in human gingival tissues collected from patients with periodontitis. An additional aim was to investigate the regulation of these enzymes with in vitro model systems mimicking an inflammatory situation. Here, we report novel findings on the localization of the $\mathrm{PGE}_{2}$-synthesizing enzymes mPGES-1, mPGES-2, and CPGES in gingival tissue from patients with periodontitis. The expression of PGE synthases and the upstream enzyme COX-2 was observed in fibroblast-like cells, vessels, epithelial cells, and immune cells. Our in vivo results were further validated by in vitro experiments, using different cell types as model systems to investigate their contribution to cytokine-stimulated $\mathrm{PGE}_{2}$ production via PGE synthases. The results suggest that inflammation-induced $\mathrm{PGE}_{2}$ production is positively regulated by the enzymes mPGES-1 and COX-2 in fibroblasts and smooth muscle cells, which might contribute to the increased $\mathrm{PGE}_{2}$ levels present in the gingival tissue of patients with periodontitis.

\section{Materials and Methods}

\section{Gingival Tissue Collection}

Eleven gingival tissue biopsies were obtained from otherwise healthy adult patients (age 35 to 68 years) diagnosed with periodontitis. For the definition of periodontitis, bone resorption resulting in a clinical attachment loss between 2 and $\geq 6 \mathrm{~mm}$, and pocket probing depth (PPD) ranging from $3 \mathrm{~mm}$ to $\geq 6 \mathrm{~mm}$ have been suggested as clinical criteria. ${ }^{29}$ The inclusion criteria used in the present study were clinical signs of periodontitis at the site of biopsy collection, including radiographical bone resorption, PPD $\geq 6 \mathrm{~mm}$, and bleeding on probing. The biopsies were taken during surgery as part of the normal course of periodontal therapy. The study was approved by the ethical committee at Karolinska Institutet. Each patient gave informed consent for the use of gingival tissue in the present study.

\section{Histological and Immunohistochemical Analysis}

Gingival tissues were either formaldehyde fixed (4\% neutral buffered formaldehyde; Apoteket, Stockholm, Sweden), processed, and paraffin-embedded or immediately snap-frozen in liquid nitrogen. For the paraffin-embedded biopsies, deparaffinized serial sections $(4 \mu \mathrm{m})$ were prepared, and sections of each biopsy were stained with hematoxylin and eosin (H\&E) and Giemsa to assess the orientation of the epithelium and the degree of cell infiltration. To investigate leukocyte infiltration in the tissues, sections were incubated with primary CD45 antibody (monoclonal mouse anti-CD45/ LCA, 1:400; Novocastra Laboratories, Newcastle upon Tyne, UK), washed, and then incubated with a BOND polymer refine detection kit using BOND DAB enhancer (Leica Microsystems-Vision BioSystems Division, Wetzlar, Germany). The staining was performed using an automated BOND-MAX instrument (Leica Microsystems).

For the immunostaining of PGE synthase, COX-2, and $\mathrm{IL}-1 \beta$ expression in the biopsies, the sections were deparaffinized using xylene and then were rehydrated through an ethanol series. Immunohistochemical staining was performed using a cell and tissue staining kit (R\&D Systems, Minneapolis, MN) according to the manufacturer's instructions. The primary antibodies used for the staining included mPGES-1 (polyclonal rabbit, 1:100), mPGES-2 (polyclonal rabbit, 1:200), cPGES (polyclonal rabbit, 1:200), COX-2 (monoclonal mouse, 1:50) (all from Cayman Chemical, Ann Arbor, MI), or IL-1 $\beta$ (monoclonal mouse, 1:400; Invitrogen, Carlsbad, CA). For negative controls, the primary antibody was substituted with isotype-matched control antibody. To identify mast cells in the tissue, sections were deparaffinized and stained either with $0.5 \%$ Toluidine Blue in Mcllvaine's buffer $(\mathrm{pH} 4)$ or with anti-human mast cell tryptase, clone AA1 (monoclonal mouse, 1:2000; DakoCytomation, Glostrup, Denmark), using an automated BOND-MAX instrument (Leica Microsystems).

For immunofluorescence double staining, frozen biopsies were cryostat-sectioned $(7 \mu \mathrm{m})$. For staining for fibroblast marker anti-prolyl-4-hydroxylase (clone 5B5) (monoclonal mouse; DakoCytomation) ${ }^{30}$ and mPGES-1, the sections were fixed and permeabilized with cold acetone and blocked with $1 \%$ bovine serum albumin in $0.25 \%$ Triton $\mathrm{X}-100$ solution. For the endothelial cell marker von Willebrand factor (clone F8/86) (monoclonal mouse; DakoCytomation) and smooth muscle actin (monoclonal mouse; DakoCytomation), the sections were fixed in $2 \%$ formaldehyde, permeabilized with $0.1 \%$ saponin, and blocked with $10 \%$ human 
serum, $1 \%$ bovine serum albumin, and $0.3 \mathrm{~mol} / \mathrm{L}$ glycine (Sigma-Aldrich, St. Louis, MO). After blocking, the slides were incubated with a mixture of two primary antibodies consisting of mPGES-1 (1:100) and either the fibroblast marker anti-prolyl-4-hydroxylase (1: 50), ${ }^{30}$ the endothelial cell marker von Willebrand factor (1:50), or smooth muscle actin (1:50). After washing, the sections were incubated with a mixture of secondary antibodies (anti-rabbit conjugated with Alexa Fluor 594 and anti-mouse conjugated with Alexa Fluor 488, dilution 1:1000; Invitrogen). The slides were mounted and observed using a Nikon fluorescence microscope, and image analysis was performed with the NIS-Elements software package (version F 2.30; Nikon Instruments, Melville, NY). For all experiments, isotypematched irrelevant antibodies were used as negative controls in the staining procedures.

\section{Cell Cultures}

Human gingival fibroblasts were established from gingival biopsies obtained from six healthy patients with no clinical signs of periodontal disease. The protocol, including the collection of gingival biopsies, was approved by the Ethical Committee at Huddinge University Hospital. Gingival fibroblasts, cultured as described previously, ${ }^{31,32}$ were seeded in 60-mm Petri dishes in Dulbecco's modified Eagle's medium (DMEM) supplemented with $5 \%$ fetal calf serum (FCS), penicillin (50 units $/ \mathrm{mL}$ ), and streptomycin $(50 \mu \mathrm{g} / \mathrm{mL}$ ) (all from Invitrogen) and then cultured. The cell layers were rinsed with serum-free DMEM, followed by the addition of DMEM containing the cytokines tumor necrosis factor $\alpha$, TNF- $\alpha$ (20 ng/mL), or IL-1 $\beta$ (0.5 ng/mL) (R\&D Systems). Control cells were treated with medium only. After the incubation (24 hours), the medium was collected and stored at $-20^{\circ} \mathrm{C}$ for $\mathrm{PGE}_{2}$ determination. The cell monolayer was washed twice with PBS, and cells were collected for flow cytometric analysis or immediately lysed for Western blot analysis.

Gingival fibroblasts from mPGES-1 knockout mice ${ }^{33}$ and wild-type mice were established from gingival biopsies collected from the palate of the mice. Mouse gingival fibroblasts were cultured using DMEM supplemented with $10 \%$ FCS, penicillin (50 units $/ \mathrm{mL}$ ), streptomycin $(50 \mu \mathrm{g} / \mathrm{mL})$, and sodium pyruvate $(100 \mathrm{mmol} /$ L). The cells were seeded in four-well chamber slides (Lab-Tek; Nalge Nunc International, Naperville, IL), cultured for 24 hours at $37^{\circ} \mathrm{C}$, and stimulated either with DMEM containing TNF- $\alpha$ or with DMEM alone (control cells). After an additional incubation period (24 hours), the medium was collected and stored at $-20^{\circ} \mathrm{C}$ for $\mathrm{PGE}_{2}$ analysis. The cell monolayers were fixed in $2 \%$ formaldehyde diluted in PBS for 15 minutes at $4^{\circ} \mathrm{C}$ and stained with polyclonal antibodies against mPGES-1 (diluted 1:5000) as described previously. ${ }^{34,35}$ Isotypematched irrelevant polyclonal antibodies were used as negative controls.

The human umbilical vein endothelial cell (HUVEC) line CRL-1730 was obtained from the American Type Culture Collection (ATCC, Manassas, VA). The cells were grown in serum-free medium (SFM; Invitrogen) supplemented with 10\% FCS (Invitrogen), penicillin (100 units $/ \mathrm{mL}$ ), streptomycin $(100 \mu \mathrm{g} / \mathrm{mL})$, and endothelial cell growth supplement (50 $\mu \mathrm{g} / \mathrm{mL}$; BD Biosciences, San Jose, CA). The cells were routinely passaged using $0.025 \%$ trypsin (Invitrogen) in PBS containing 0.02\% EDTA. Endothelial cells were seeded in 60-mm Petri dishes and were cultured for 24 hours. The cells were washed with medium containing all supplements except FCS, followed by addition of the same medium with or without IL- $1 \beta$ or TNF- $\alpha$. After 24 hours of incubation, the medium was collected and stored at $-20^{\circ} \mathrm{C}$ for $\mathrm{PGE}_{2}$ measurements; the cells were collected for flow cytometric analysis or lysed for Western blot analysis, as described above.

Primary cultures of human airway smooth muscle (HASM) cells were prepared from explants of human airway smooth muscle as previously reported ${ }^{36}$ and cultured in DMEM containing 10\% FCS, penicillin (50 units/ $\mathrm{mL})$, and streptomycin $(50 \mathrm{~g} / \mathrm{mL})$ at $37^{\circ} \mathrm{C}$. The cells were trypsinized and seeded in 60-mm Petri dishes in culture medium. The smooth muscle cells were rinsed with DMEM without FCS, followed by addition of serum-free culture medium with or without IL-1 $\beta$ or TNF- $\alpha$. After 24 hours of incubation, the medium was collected and stored at $-20^{\circ} \mathrm{C}$ for $\mathrm{PGE}_{2}$ analyses; the cells were collected for flow cytometric or Western blot analysis.

The human mast cell line HMC-1.2 (a subclone of the cell line HMC-1) and human primary mast cells (cord blood mast cells) were isolated and prepared as previously described. ${ }^{37-39}$ The HMC-1.2 cells were cultured in Iscove's modified Dulbecco's medium supplemented with penicillin (50 units $/ \mathrm{mL})$, streptomycin $(50 \mu \mathrm{g} / \mathrm{mL})$, monothioglycerol (1.5 mmol/L), and 10\% FCS. Primary mast cells were cultured in RPMI 1640 medium in the presence of recombinant human stem cell factor (100 $\mathrm{ng} / \mathrm{mL}$; kindly provided by Amgen, Thousand Oaks, CA) and rhIL-6 (10 ng/mL; kindly provided by Amgen) and supplemented with $10 \% \mathrm{FCS}, 50 \mu \mathrm{mol} / \mathrm{L}$ 2-mercaptoethanol, $2 \mathrm{mmol} / \mathrm{L}$ L-glutamine, $0.1 \mathrm{mmol} / \mathrm{L}$ nonessential amino acids, $100 \mathrm{U} / \mathrm{mL}$ penicillin, and $50 \mu \mathrm{g} / \mathrm{mL}$ streptomycin (Sigma-Aldrich). Before stimulation, cells were washed with complete growth medium without FCS. The cells were centrifuged and resuspended in serum-free medium with or without TNF- $\alpha$ or IL-1 $\beta$. After incubation (24 hours), the medium was collected for $\mathrm{PGE}_{2}$ determination and the cells were collected for flow cytometric or Western blot analysis as described above.

Coculture experiments were performed with lymphocytes isolated from whole blood using Ficoll-Paque PLUS (GE Healthcare Life Sciences, Piscataway, NJ) according to the manufacturer's instructions. Fibroblasts, endothelial cells, or smooth muscle cells were cultured and seeded $\left(5 \times 10^{5}\right.$ cells) in 60-mm Petri dishes as described above. The cells were rinsed and cultured either alone or in coculture with lymphocytes $\left(2.5 \times 10^{6}\right)$ resuspended in appropriate medium as previously described. ${ }^{40}$ After 18 hours of incubation, the coculture medium containing lymphocytes was removed and centrifuged, after which the medium was collected and stored at $-20^{\circ} \mathrm{C}$ for $\mathrm{PGE}_{2}$ measurements. Fibroblasts, HUVECs, or HASM cells were trypsinized. All of the cell 

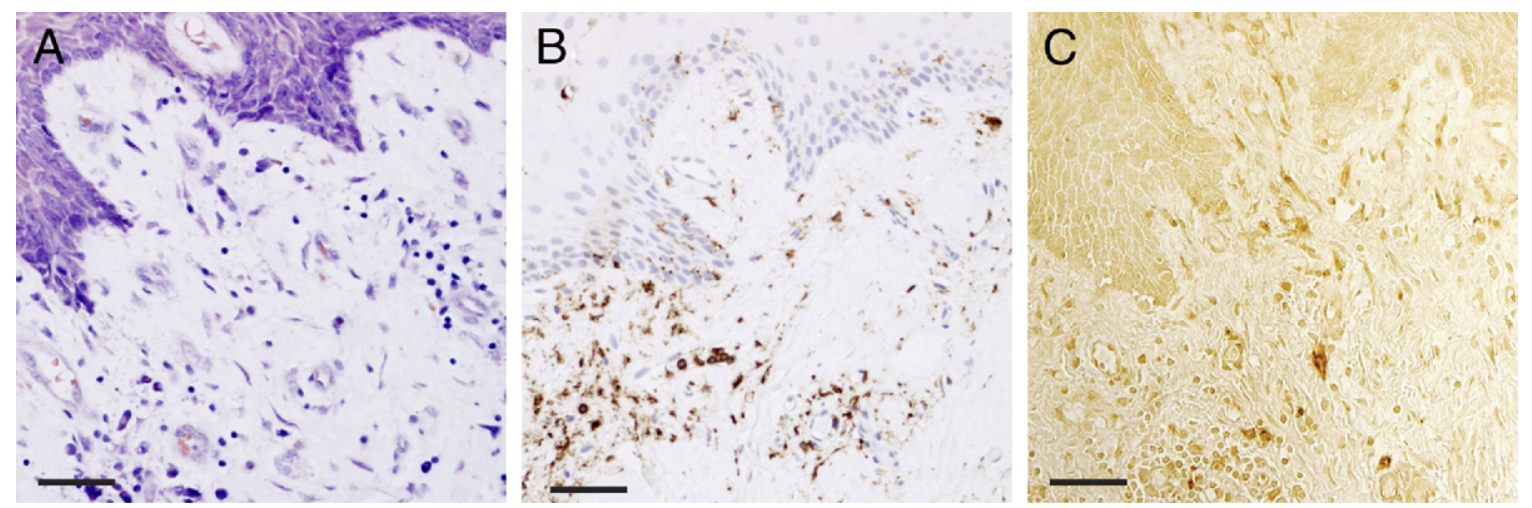

Figure 1. Contrast staining and immunohistochemical staining of CD 45 and IL-1 $\beta$ in gingival tissue of a representative biopsy from a patient with periodontitis All images are taken from the same area. A: Giemsa contrast staining for tissue morphology. B: CD 45 and H\&E staining, showing immune cells. C: Immunohistochemical staining for the inflammatory cytokine IL- $1 \beta$. Scale bars $=50 \mu \mathrm{m}$.

types, including lymphocytes, were collected and analyzed by flow cytometry.

\section{Western Blot Analysis}

Cells were seeded and cultured as described above. To isolate the total protein, the cells were resuspended in PBS and the pellet was resuspended in lysis buffer consisting of $10 \mathrm{mmol} / \mathrm{L}$ HEPES $\mathrm{pH} 7.9,10 \mathrm{mmol} / \mathrm{L} \mathrm{KCl}, 0.1$ $\mathrm{mmol} / \mathrm{L}$ EDTA, $0.1 \mathrm{mmol} / \mathrm{L}$ EGTA, $1 \mathrm{mmol} / \mathrm{L}$ dithiothreitol, and protease inhibitors $[1 \mathrm{mmol} / \mathrm{L}$ phenylmethylsulfonyl fluoride, pepstatin, aprotinin, and leupeptin at $1 \mu \mathrm{g} / \mathrm{mL}$ (all from Sigma-Aldrich)]. Protein concentration was determined, and equal amounts of the protein were separated by electrophoresis on a $4 \%-15 \%$ linear gradient polyacrylamide Tris-HCl gel (Bio-Rad Laboratories, Hercules, CA) and immunoblotted as previously described. ${ }^{31,32}$

\section{Flow Cytometric Analysis}

Cells were seeded and grown as described above. After treatment, the cells were collected by trypsinization and/or centrifugation of culture medium, depending on cell type, and washed with PBS. The cells were then fixed in $2 \%$ paraformaldehyde and washed with PBS before permeabilization with PBS containing $0.1 \%$ saponin and $0.01 \mathrm{M}$ HEPES and flow cytometric analysis was performed as previously described. ${ }^{31}$ For each sample, 10,000 events were acquired. A gated area for the particular cell type was determined using forward versus side scatter parameters, and the gated cells were analyzed for expression of mPGES-1, mPGES-2, cPGES, or COX-2. The results obtained are either shown as histograms of cell counts drawn using the R programming environment (version 2.4.0, R Development Core Team; http://www.r-project.org) together with the R software package RFlowCyt, or are presented as mean fluorescence intensity $(\mathrm{MFI}) .{ }^{41}$

\section{Prostaglandin $E_{2}$ Determination}

The amount of $\mathrm{PGE}_{2}$ in the culture medium collected from control, cytokine-stimulated, or cocultured cells was de- termined by enzyme immunoassay using a Luminex $\mathrm{PGE}_{2}$ kit (Cayman Chemical) and Bio-Plex suspension array system (Bio-Rad Laboratories) and a conventional EIA kit (Cayman Chemical).

\section{Statistical Analysis}

Cell culture experiments were analyzed in triplicate, and reproducible data representing one of at least three independent experiments is demonstrated. Results are expressed as the mean \pm SD. Student's $t$-test (two-tailed) was used in the statistical analysis, and $P$ values of $<0.05$ were considered statistically significant.

\section{Results}

\section{Presence of CD45 and IL-1 $\beta$ in Gingival Tissue of Patients with Periodontitis}

Serial paraffin sections of gingival biopsies obtained from patients with periodontitis were stained with Giemsa and H\&E histological methods, as well as for CD45 and IL-1 $\beta$ as markers of inflammation. ${ }^{42,43}$ A representative photomicrograph of gingival tissue stained with Giemsa, demonstrating the presence of immune cells in the tissue, is presented in Figure 1A. The leukocyte marker CD45 (LCA, leukocyte common antigen) was used to assess the histological grade of inflammation, shown in double staining with $\mathrm{H} \& \mathrm{E}$ (Figure $1 \mathrm{~B})$. In addition, the biopsies were also stained for the pro-inflammatory cytokine $\mathrm{IL}-1 \beta$, demonstrating ubiquitous expression of this mediator in the gingival tissue (Figure $1 \mathrm{C}$ ). Altogether, the immunostaining of gingival biopsies showed an infiltrate of immune cells, as well as detection of $\mathrm{IL}-1 \beta$, demonstrating the presence of inflammation of the gingival tissue obtained from patients with periodontitis (Figure 1).

\section{PGE Synthases Are Expressed in Gingival Tissue of Patients with Periodontitis}

We first investigated the expression and localization of PGE synthases in 11 gingival biopsies collected from 


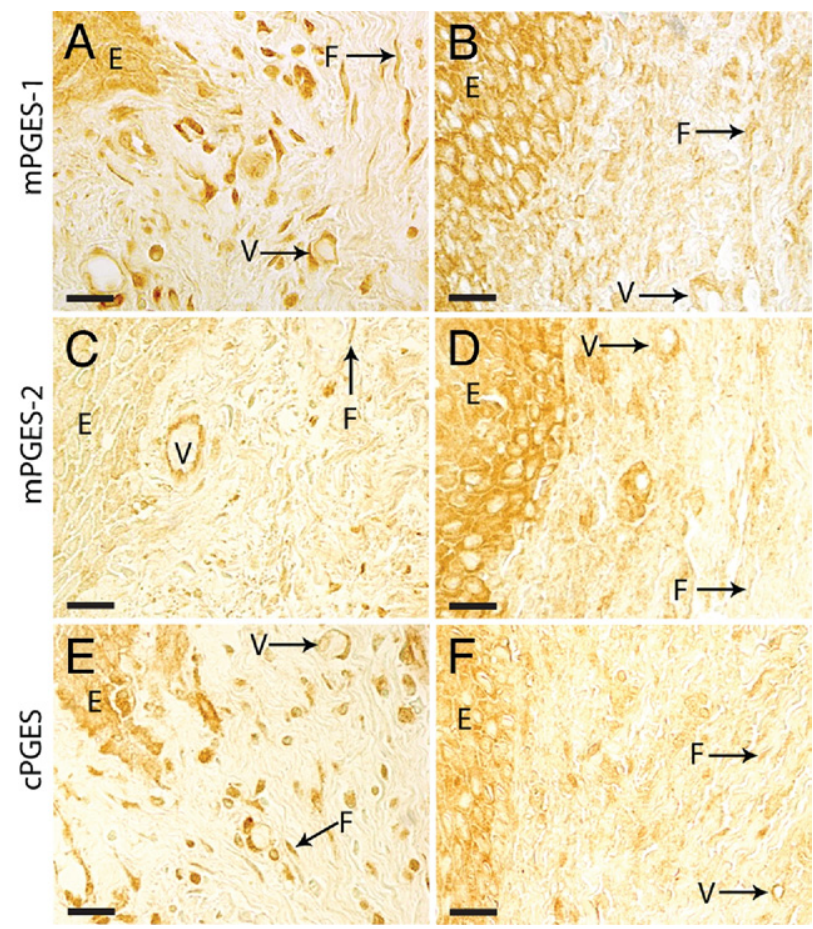

Figure 2. Immunohistochemical localization of PGE synthases in gingival tissue from two representative patients with periodontitis, stained against mPGES-1 (A and B), mPGES-2 (C and D), or CPGES (E and $\mathbf{F}) . \mathbf{A}, \mathbf{C}$, and $\mathbf{E}$ : One biopsy. B, D, and $\mathbf{F}$ : The other biopsy. E, epithelium, F, fibroblast-like cell; V, vessel. Scale bars $=20 \mu \mathrm{m}$

patients with periodontitis. Immunohistochemical staining of mPGES-1, mPGES-2, and cPGES produced positive cells in the gingival tissues from subjects with periodontitis, as seen from biopsies from two representative patients with periodontitis (Figure 2). Microscopic analysis of the sections showed that the expression of the three PGE synthases was localized to fibroblast-like cells, vessels (endothelial cells and smooth muscle cells), epithelial cells, and immune cells (Figure 2). Immunohistochemical staining of the upstream enzyme COX-2, used as a control in this study, also resulted in positively stained fibroblast-like cells, vessels, epithelial cells, and immune cells in the gingival tissue (Figure 3). Control stainings with the isotype-matched irrelevant antibodies were negative (data not shown).

\section{mPGES-1 Protein Expression Is Increased by TNF- $\alpha$ and IL-1 $\beta$ in Gingival Fibroblasts}

To further explore the cellular source of inflammatory increased $\mathrm{PGE}_{2}$ production, and to clarify the involvement of the PGE synthases, we performed cell culture experiments using cell types that were positively stained for $\mathrm{PGE}_{2}$-synthesizing enzymes in gingival connective tissue. To mimic an in vivo inflammation in vitro, we stimulated cell cultures of fibroblasts, endothelial cells, smooth muscle cells, and mast cells with the inflammatory cytokines TNF- $\alpha$ and IL- $1 \beta$ and then investigated the expression of mPGES-1, mPGES-2, and CPGES in parallel with COX-2 expression and $\mathrm{PGE}_{2}$ production. We focused first on human gingival fibroblasts, which are the most abundant cells in gingival connective tissue.

In immunohistochemical staining of gingival biopsies for PGE synthases, fibroblast-like cells were positively stained, as demonstrated by mPGES-1 staining (Figure 4A). Co-immunostaining of mPGES-1 and the fibroblast marker prolyl-4-hydroxylase (5B5) showed colocalization of mPGES-1 and prolyl-4-hydroxylase in fibroblasts of gingival tissue (Figure 4, B-D). For in vitro experiments, gingival fibroblasts were treated with the inflammatory cytokines TNF- $\alpha$ and IL-1 $\beta$ (as described under Materials and Methods). In accord with our previous findings, ${ }^{31}$ the production of $\mathrm{PGE}_{2}$ was markedly increased by the cytokines (Figure 4E). Furthermore, Western blot analysis revealed that expression of both mPGES- 1 and COX-2 was concomitantly increased by the cytokines TNF- $\alpha$ and IL-1 $\beta$, whereas mPGES-2 and CPGES expression was constitutive and unaffected by cytokine treatment (Figure 4F). The up-regulation of mPGES-1 and COX-2, as well as the lack of induction of mPGES-2 and cPGES, in gingival fibroblasts was also confirmed by flow cytometric analysis (Figure 4G).

\section{PGE Synthases Are Not Affected by TNF- $\alpha$ and $I L-1 \beta$ in Endothelial Cells}

Our immunohistochemical analysis of the in vivo expression of PGE synthases revealed positive staining of vessels, including endothelial cells, as seen in a representative staining of mPGES-1 (Figure 5A). Immunostaining of mPGES-1 and the endothelial cell marker von Willebrand factor showed colocalization of mPGES-1 and von Willebrand factor in endothelial cells of gingival tissue (Figure 5, B-D). We further investigated the expression of $\mathrm{PGE}$ synthases and COX-2 in relation to $\mathrm{PGE}_{2}$ production, using a human umbilical vein endothelial cell line (HUVEC) as an in vitro model. $\mathrm{PGE}_{2}$ production in HUVECs was significantly increased only by the inflammatory cytokine TNF- $\alpha$ (Figure 5E). The protein expression of mPGES-1, mPGES-2, and cPGES remained unaffected by the cytokine treatment, as demonstrated by Western blot analysis (Figure 5F); however, an increase of COX-2 protein

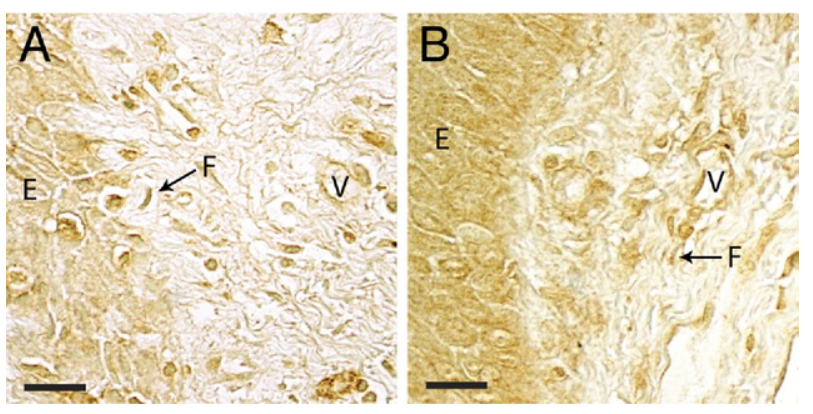

Figure 3. Immunohistochemical localization of COX-2 in gingival tissue from representative biopsies from two different patients ( $\mathbf{A}$ and $\mathbf{B}$ ) with periodontitis. E, epithelium, F, fibroblast-like cell; V, vessel. Scale bars $=20 \mu \mathrm{m}$. 

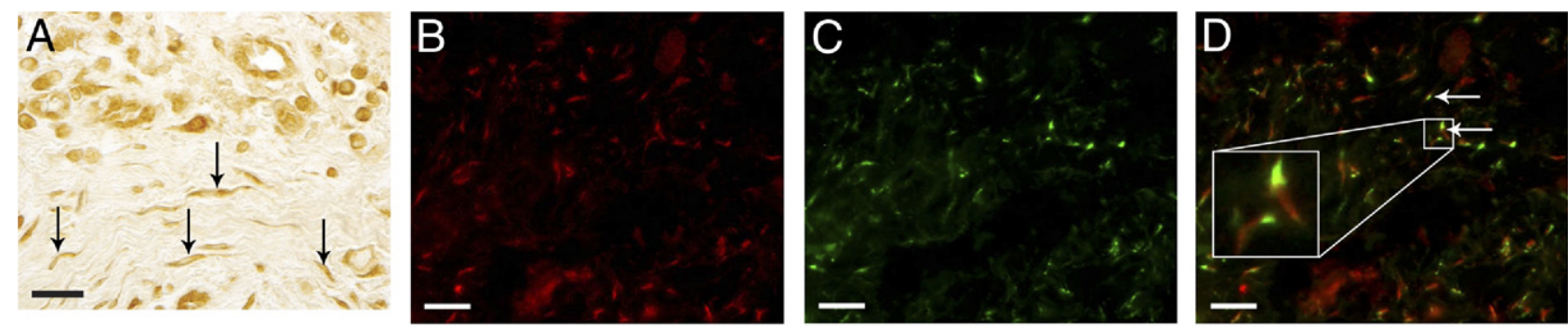

$\mathrm{E}$

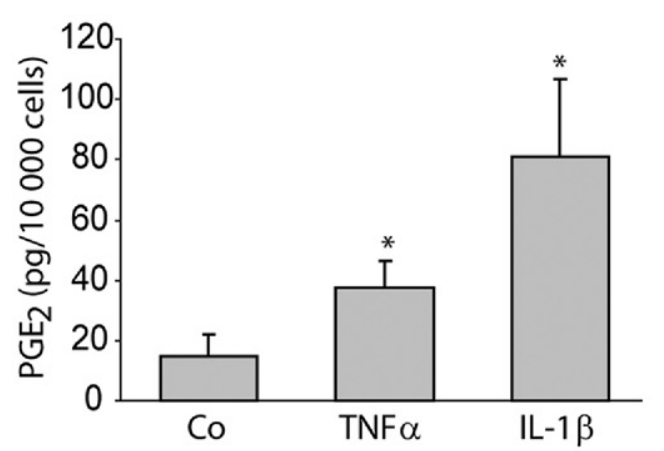

$\mathrm{F}$ Co $\quad$ TNF $\alpha \quad$ IL-1 $\beta$
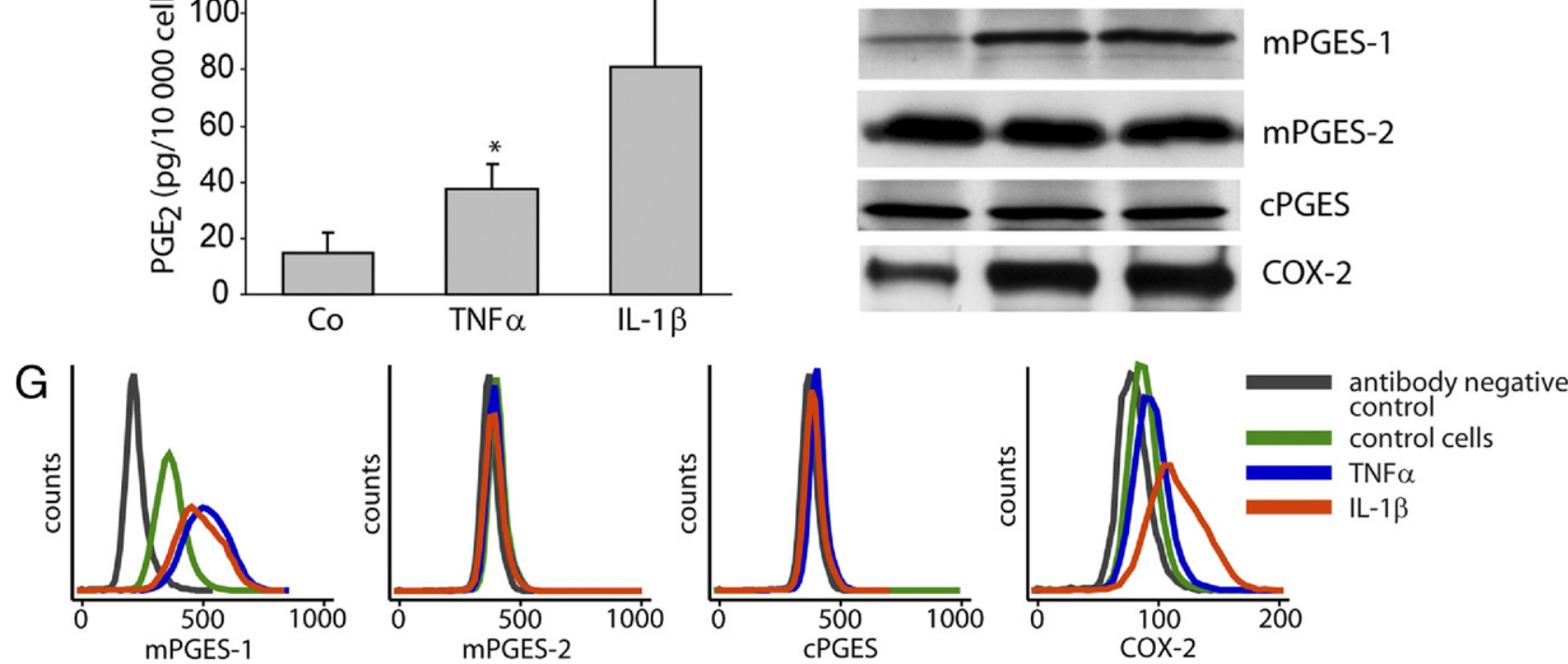

Figure 4. Production of $\mathrm{PGE}_{2}$ and expression of PGE synthases and COX-2 after treatment with TNF- $\alpha(20 \mathrm{ng} / \mathrm{mL})$ or IL- $1 \beta(0.5 \mathrm{ng} / \mathrm{mL})$ in gingival fibroblasts. A: Representative immunohistochemical mPGES-1 staining of a gingival biopsy from a patient with periodontitis, showing positively stained fibroblast-like cells (arrows). B: Fluorescent staining of mPGES-1 using Alexa Fluor 594-conjugated secondary antibody (red). C: Fluorescent staining of fibroblasts using fibroblast antibody prolyl-4-hydroxylase (5B5) and Alexa Fluor 488-conjugated secondary antibody (green). D: Merged image of mPGES-1 and prolyl-4-hydroxylase staining showing mPGES-1 expression in fibroblasts (arrows). E: In vitro production of $\mathrm{PGE}_{2}$ in gingival fibroblasts; control cells (Co) $15 \pm 7$ pg PGE $2 / 10,000$ cells, TNF- $\alpha$-stimulated $38 \pm 9$ pg PGE $2 / 10,000$ cells, and IL- $1 \beta$-stimulated $81 \pm 26$ pg PGE $/ 10,000$ cells. ${ }^{*} P<0.05$ compared with control cells. F: Expression of PGE synthases and COX-2 in gingival fibroblasts as detected by Western blot. G: Expression of PGE synthases and COX-2 in gingival fibroblasts as analyzed by flow cytometry. All analyses were performed in triplicate. Results shown are representative from at least three independent experiments. Scale bars $=20 \mu \mathrm{m}$.

expression in response to TNF- $\alpha$ was observed, as demonstrated by Western blot analysis (Figure $5 \mathrm{C}$ ). The increased COX-2 expression in TNF- $\alpha$-stimulated cells was also confirmed by flow cytometric analysis (Figure 5G).

\section{mPGES-1 Protein Expression Is Increased by TNF- $\alpha$ and IL-1 $\beta$ in Smooth Muscle Cells}

Vessels consisting of smooth muscle cells and endothelial cells were positively stained for the $\mathrm{PGE}_{2}$-synthesizing enzymes mPGES-1, mPGES-2, and cPGES in gingival biopsies from representative patients with periodontitis. A representative gingival biopsy demonstrating positive staining of mPGES-1 in vascular smooth muscle cells is presented in Figure 6A. In addition, co-immunostaining of mPGES-1 and smooth muscle actin demonstrated colocalization of mPGES-1 and actin in vascular smooth muscle cells of gingival tissue (Figure 6, B-D). To study the regulation of $\mathrm{PGE}_{2}$-synthesizing enzymes and subsequent $\mathrm{PGE}_{2}$ production in smooth muscle cells, we used HASM cells as an in vitro model. When HASM cells were treated with the pro-inflammatory cytokines TNF- $\alpha$ or IL-
$1 \beta$, the production of $\mathrm{PGE}_{2}$ increased markedly (Figure $6 \mathrm{E})$. Similarly, the protein expression of the enzymes mPGES-1 and COX-2 was also up-regulated by the cytokines, as demonstrated by Western blot (Figure 6F). Flow cytometric analyses, in accord with the Western blot results, showed an up-regulation of both mPGES-1 and COX-2 in response to TNF- $\alpha$ and $\mathrm{IL}-1 \beta$, whereas mPGES-2 and cPGES remained unaffected (Figure 6, $F$ and $G$ ).

Protein Expression of PGE Synthases and PGE Production Is Not Affected by Cytokines in Mast Cells

In immunohistochemical staining of gingival biopsies for PGE synthases and COX-2, immune cells were positively stained, as seen in a representative mPGES-1 staining (Figure 7A). Using the metachromatic interaction between mast cell granules and Toluidine Blue as a method of identifying mast cells, we confirmed that mast cells were present among the immune cells in the gingival tissue, as seen from a representative example of a gin- 

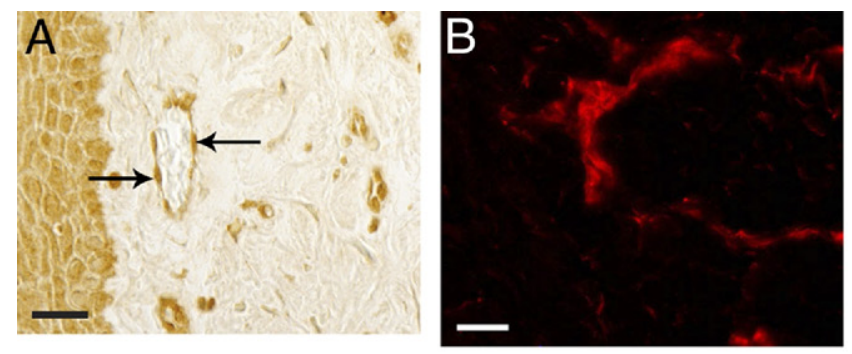

\section{E}

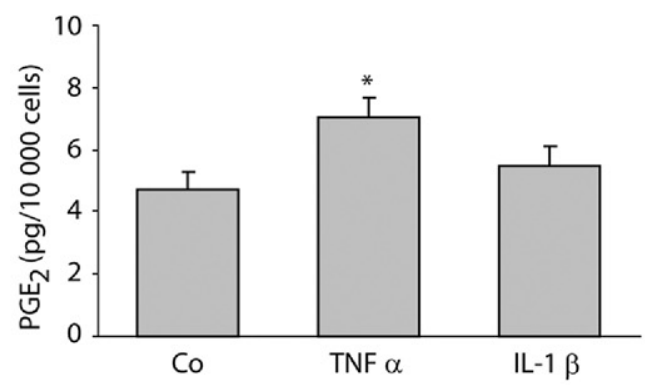

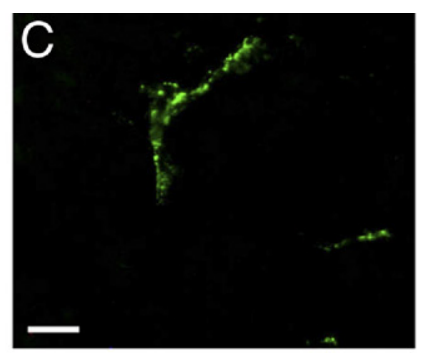

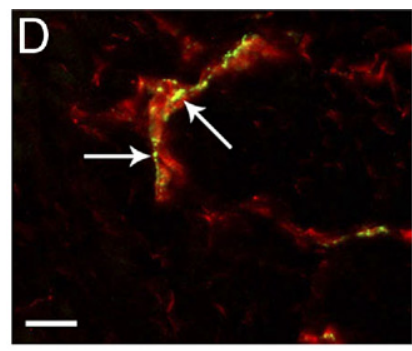

F

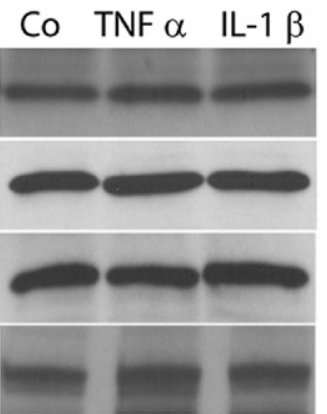

mPGES-1

\section{mPGES-2}

CPGES

COX-2
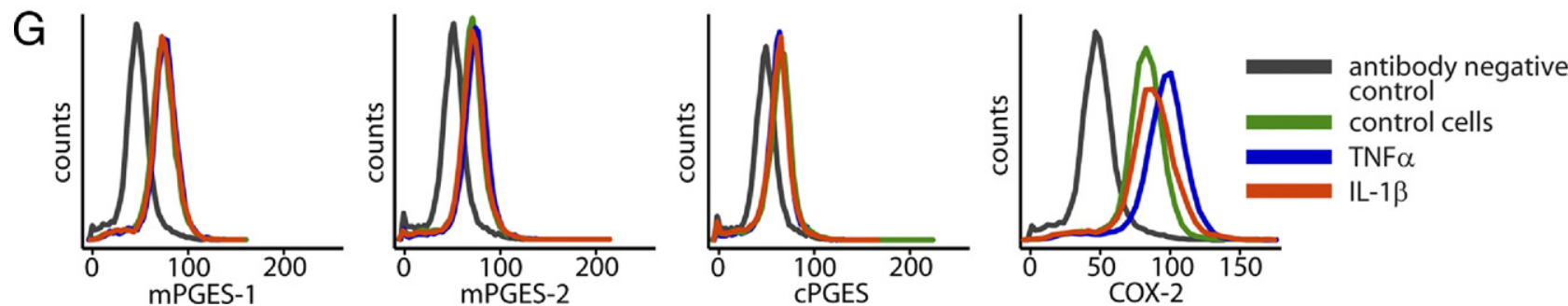

Figure 5. Production of $\mathrm{PGE}_{2}$ and expression of PGE synthases and COX-2 after stimulation with TNF- $\alpha$ (20 ng/mL) or IL- $1 \beta$ ( $\left.0.5 \mathrm{ng} / \mathrm{mL}\right)$ in $\mathrm{HUVECs}$ A: Representative immunohistochemical mPGES-1 staining of a gingival biopsy, showing positively stained endothelial cells (arrows). B: Fluorescent staining of mPGES-1 using Alexa Fluor 594-conjugated secondary (red). C: Fluorescent staining of endothelial cells using anti-human von Willebrand factor (green). D: Merged image of mPGES-1 and von Willebrand factor staining showing mPGES-1 expression in endothelial cells (arrows). E: In vitro production of $\mathrm{PGE}_{2}$ in HUVECs; control cells (Co) $4.7 \pm 0.6 \mathrm{pg} \mathrm{PGE} / 10,000$ cells, TNF- $\alpha$-treated cells $7.1 \pm 0.6$ pg PGE $/ 10,000$ cells, and IL- $1 \beta$-treated cells $5.5 \pm 0.6$ pg $\mathrm{PGE}_{2} / 10,000$ cells. ${ }^{*} P<0.05$ compared with control cells. F: Expression of PGE synthases and COX-2 in HUVECs as detected by Western blot. G: Expression of PGE synthases and COX-2 in HUVECs as analyzed by flow cytometry. All analyses were performed in triplicate. Results shown are representative from at least three independent experiments. Scale bars $=20 \mu \mathrm{m}$.

gival biopsy (Figure 7B). Staining for the mast cell marker tryptase further confirmed the identity of mast cells in the tissue (Figure 7C). Because the expression of PGE synthases has not, to our knowledge, been investigated previously in mast cells, this particular type of immune cell was included in the in vitro analyses.

To investigate the in vitro expression of PGE synthases and production of $\mathrm{PGE}_{2}$ in mast cells, we stimulated human mast cells of the cell line HMC-1.2 with the inflammatory cytokines TNF- $\alpha$ and IL-1 $\beta$. The results showed a basal production of $\mathrm{PGE}_{2}$ by mast cells, but no changes in $\mathrm{PGE}_{2}$ production were observed in response to the inflammatory cytokines (Figure 7D). All three PGE synthases and COX-2 were constitutively expressed in unstimulated mast cells, but neither PGE synthase nor COX-2 expression was affected by TNF- $\alpha$ or IL- $1 \beta$ treatment, as assessed by Western blot analyses (Figure 7E). In addition to the mast cell line, primary cord blood mast cells were also included to investigate mPGES-1 and COX-2 expression. The flow cytometry results showed no up-regulation of either mPGES-1 or COX-2 expression in response to TNF- $\alpha$ or IL- $1 \beta$ treatment (Figure 7F). Furthermore, these primary mast cells, in accordance with our results on the cell line $\mathrm{HMC}-1.2$, produced $\mathrm{PGE}_{2}$ at a basal level, which did not increase by TNF- $\alpha$ or IL-1 $\beta$ treatment (data not shown).

\section{Increased Protein Expression of mPGES-1 and COX-2, and Production of PGE 2 , in Cocultures of Lymphocytes with Fibroblasts or Smooth Muscle Cells}

To investigate the interaction between lymphocytes and the cell types expressing mPGES-1 and COX-2 enzymes, coculture experiments were performed. Coculture of fibroblasts or HASM cells with lymphocytes resulted in increased mPGES-1 and COX-2 expression in fibroblasts and in HASM cells (Table 1). Similarly, $\mathrm{PGE}_{2}$ production increased in fibroblasts and HASM cells when cocultured with lymphocytes (Table 1). Furthermore, when fibroblasts, the most ubiquitous cell type in gingival connective tissue, were cocultured with lymphocytes in the presence of the cytokines $\mathrm{IL}-1 \beta$ or TNF- $\alpha$, no additional increase of $\mathrm{PGE}_{2}$-synthesizing enzymes or $\mathrm{PGE}_{2}$ production was observed (data not shown). In the HUVEC cell 

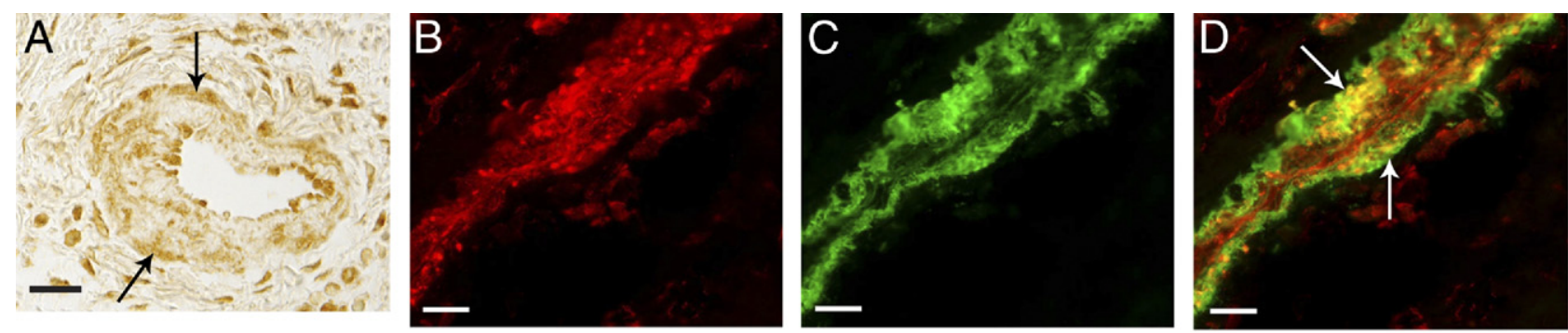

E

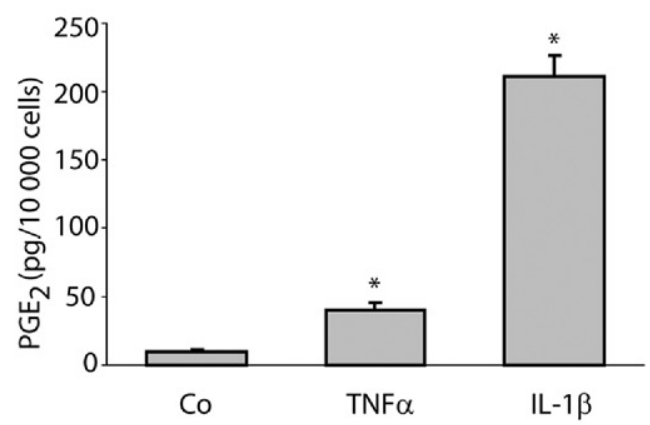

$\mathrm{F}$

Co TNF $\alpha \quad$ IL-1 $\beta$

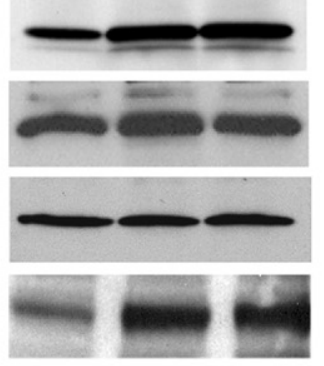

mPGES-1

MPGES-2

CPGES

$\operatorname{cox}-2$
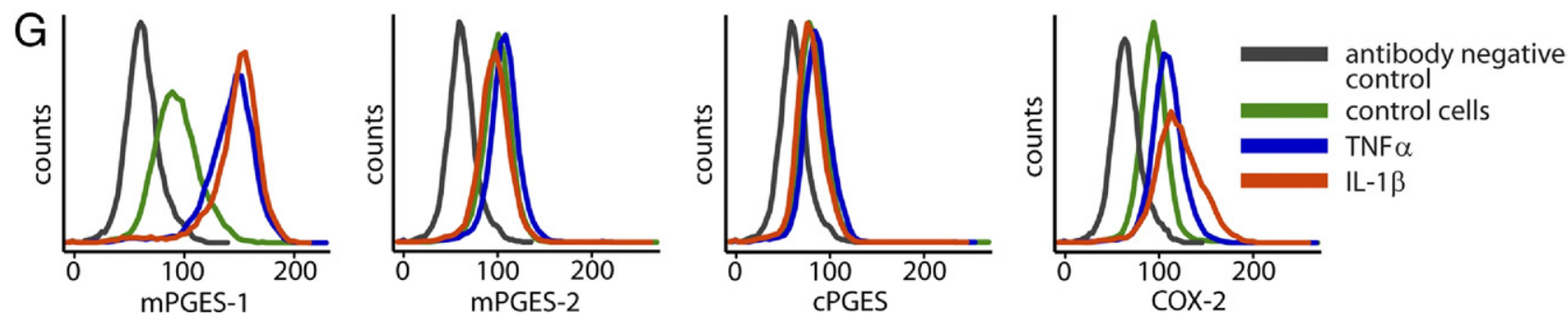

Figure 6. Production of $\mathrm{PGE}_{2}$ and expression of PGE synthases and COX-2 after stimulation with TNF- $\alpha$ ( $\left.20 \mathrm{ng} / \mathrm{mL}\right) \mathrm{or}$ IL- $1 \beta$ ( $\left.0.5 \mathrm{ng} / \mathrm{mL}\right)$ in HASM cells A: Representative immunohistochemical mPGES-1 staining of a gingival biopsy, showing positive vascular smooth muscle cells (arrows). B: Fluorescent staining of mPGES-1 using Alexa Fluor 594-conjugated secondary antibody (red). C: Fluorescent staining of smooth muscle cells using anti-human smooth muscle actin and Alexa Fluor 488-conjugated secondary antibody (green). D: Merged image of mPGES-1 and smooth muscle actin showing mPGES-1 expression in smooth muscle cells (arrows). E: In vitro production of $\mathrm{PGE}_{2}$ in HASM cells; control cells (Co) $10 \pm 0.6$ pg PGE $2 / 10,000$ cells, TNF- $\alpha$-stimulated $40 \pm 6$ pg PGE $2 / 10,000$ cells, and IL-1 $\beta$-stimulated $211 \pm 16$ pg PGE $/ 10,000$ cells. ${ }^{*} P<0.05$ compared with control cells. F: Expression of PGE synthases and COX-2 in HASM cells as detected by Western blot. G: Expression of PGE synthases and COX-2 in HASM cells as analyzed by flow cytometry. All analyses were performed in triplicate. Results shown are representative from at least three independent experiments. Scale bars $=20 \mu \mathrm{m}$.

line, however, neither the expression of mPGES-1 and COX-2 enzymes nor the production of $\mathrm{PGE}_{2}$ was affected when cocultured with lymphocytes (Table 1).

\section{mPGES-1 Protein Expression and PGE 2}

\section{Production Are Reduced in Gingival Fibroblasts Isolated from mPGES-1 Knockout Mice}

To explore the role of mPGES-1 in the regulation of $\mathrm{PGE}_{2}$ in gingival tissue, we also used mPGES-1 null gingival fibroblasts derived from mPGES-1 knockout mice. ${ }^{44}$ The mPGES-1 knockout cells produced significantly lower basal levels of $\mathrm{PGE}_{2}$ (88\% decrease), compared with $\mathrm{PGE}_{2}$ synthesis in gingival fibroblasts derived from wild-type mice (Figure $8 \mathrm{~A}$ ). Similarly, the TNF- $\alpha$-stimulated $\mathrm{PGE}_{2}$ production was strongly reduced ( $80 \%$ decrease) in $\mathrm{mPGES}-1$ null gingival fibroblasts, compared with wild-type cells (Figure 8A). Immunostaining of mPGES-1 revealed no induction of mPGES- 1 expression in TNF- $\alpha$-stimulated mPGES- 1 null gingival fibroblasts (Figure 8I), compared with un- treated control cells (Figure $8 \mathrm{H}$ ). In contrast, wild-type fibroblasts showed increased expression of mPGES-1 in response to TNF- $\alpha$ (Figure 8E), compared with untreated control cells (Figure 8D).

\section{Discussion}

The PGE synthases mPGES-1, mPGES-2, and cPGES are the terminal enzymes in the synthesis of $\mathrm{PGE}_{2}$, a potent mediator associated with the chronic inflammatory disease periodontitis. As a novel outcome of the present study, we have demonstrated the cellular localization of all three PGE synthases in gingival tissue from patients with periodontitis. Immunohistochemical analysis showed the expression of the PGE synthases mPGES-1, mPGES-2, and CPGES, as well as of the upstream enzyme COX-2, to be localized to vessels, fibroblast-like cells, immune cells, and epithelium. Co-immunostaining using cell type-specific markers confirmed in vivo mPGES-1 expression in fibroblasts, smooth muscle cells, and endothelial cells of inflamed gingival tissue. To in- 

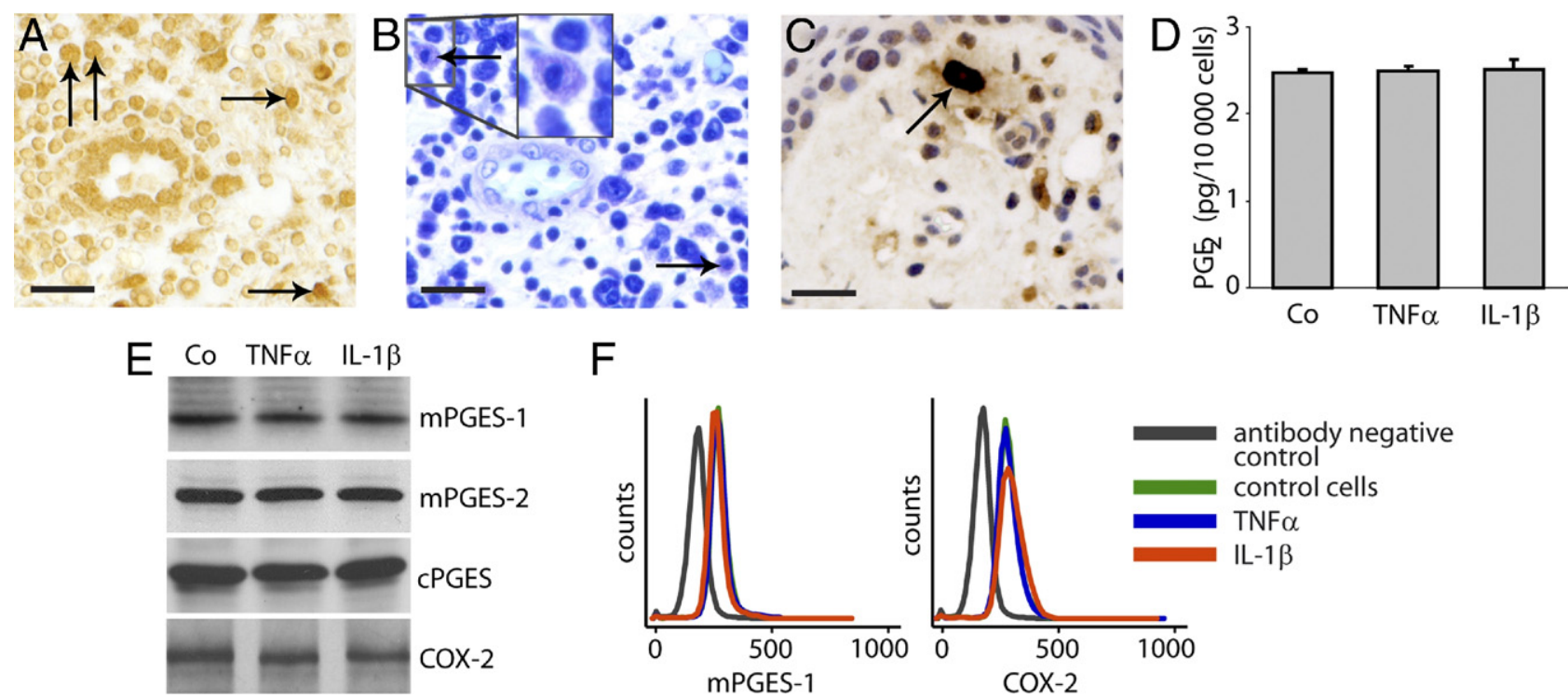

Figure 7. Localization in gingival tissue, with $\mathrm{PGE}_{2}$ production and expression of PGE synthases and COX-2 in cultured cells stimulated with TNF- $\alpha$ (20 ng/mL) or IL-1 $\beta(0.5 \mathrm{ng} / \mathrm{mL})$ in human mast cells. A: Representative immunohistochemical mPGES-1 staining of a gingival biopsy, showing positive immune cells (arrows). Toluidine Blue staining (B) and immunostaining using the mast cell marker tryptase (C) of gingival tissues from patients with periodontitis showing the presence of mast cells (arrows). A and $\mathbf{B}$ are from the same biopsy, and $\mathbf{C}$ is from another. D: In vitro production of PGE 2 in the mast cell line HMC-1.2; control cells (Co) $2.5 \pm 0.02 \mathrm{pg} \mathrm{PGE} / 2 / 10,000$ cells, TNF- $\alpha$-treated cells $2.5 \pm 0.06 \mathrm{pg} \mathrm{PGE} / 10,000$ cells, and IL- $1 \beta$-treated cells $2.5 \pm 0.12$ pg PGE $/ 10,000$ cells. E: Expression of PGE synthase and COX-2 in the mast cell line HMC-1.2 as detected by Western blot. F: Expression of mPGES-1 and COX-2 in primary mast cells as detected by flow cytometry. All analyses were performed in triplicate. Results shown are representative from at least three independent experiments. Scale bars $=20 \mu \mathrm{m}$

vestigate the expression of the $\mathrm{PGE}_{2}$-synthesizing enzymes and their contribution to inflammation-induced $\mathrm{PGE}_{2}$ production, in vitro experiments using various cell culture model systems were performed. The results showed protein expression of mPGES-1, mPGES-2, cPGES, and COX-2 in cultured fibroblasts, endothelial cells, and, as a novel finding, also in smooth muscle cells and mast cells. Moreover, mPGES- 1 and COX-2 protein expression was increased by both TNF- $\alpha$ and IL- $1 \beta$ treatment in fibroblasts and smooth muscle cells, whereas in endothelial cells only COX-2 was induced in response to TNF- $\alpha$ treatment.

The immunohistochemical results showed that the expression of PGE synthases and the upstream enzyme COX-2 was localized to vessels, fibroblast-like cells, and immune cells in gingival connective tissue from patients with periodontitis. The in vivo expression of all three PGE synthase isoforms has not been previously investigated in gingival tissue, although mPGES-1 and COX-2 have been shown to be expressed in gingivitis. ${ }^{25}$ Our results concerning the lo- calization of mPGES-1 and COX-2 are consistent with previously published results showing positive staining of mPGES-1 and COX-2 in epithelial, endothelial, and fibroblast-like connective tissue cells of the gingiva. ${ }^{25,27}$ In regard to nonoral chronic inflammatory conditions, the isoenzymes mPGES-1 and cPGES are reported to be expressed in synovial tissue sections from patients with the chronic inflammatory disease rheumatoid arthritis. ${ }^{35}$ Furthermore, the expression of all three PGE synthases has been reported in gastric ulcer tissue, demonstrating strong mPGES-1 expression in fibroblasts and macrophages of the ulcer bed. ${ }^{45}$

Given that levels of $\mathrm{PGE}_{2}$ have been shown to be increased in gingival crevicular fluid from patients with periodontitis, compared with healthy controls, it is important to investigate the cellular sources of this inflammatory mediator in gingival tissue. ${ }^{46,47}$ To gain further insight into the contribution and regulation of $\mathrm{PGE}_{2}$ production, we investigated the in vitro protein expression of PGE synthases in the cell types that were positively stained in gingival connective tissue. The cytokines

Table 1. Effect of Lymphocytes on mPGES-1 and COX-2 Expression and PGE 2 Production In Cocultures of Gingival Fibroblasts, HUVECs, and HASM Cells

\begin{tabular}{|c|c|c|c|c|c|c|}
\hline & \multicolumn{2}{|c|}{ mPGES-1, MFI (SD) } & \multicolumn{2}{|c|}{ COX-2, MFI (SD) } & \multicolumn{2}{|c|}{$\mathrm{PGE}_{2}$ (pg/10,000 adherent cells) } \\
\hline & - & + & - & + & - & + \\
\hline Fibroblasts & $15.3(7.3)$ & $88.1(35.3)^{\star}$ & $12.0(5.7)$ & $139.2(71.5)^{\star}$ & $5.4(0.1)$ & $1141.4(124.6)^{\star}$ \\
\hline HUVECs & $22.5(8.9)$ & $21.5(8.6)$ & $16.5(5.5)$ & $16.1(5.5)$ & $0.6(0.2)$ & $1.3(0.4)$ \\
\hline HASM cells & $72.7(36.5)$ & $205.9(93.8)^{\star}$ & $30.4(12.0)$ & $161.7(65.5)^{\star}$ & $10.1(0.9)$ & $953.8(30.1)^{*}$ \\
\hline
\end{tabular}

HUVEC, human umbilical vein endothelial cell; MFI, mean fluorescence intensity (arbitrary units); +, cocultured with lymphocytes; -, not cocultured with lymphocytes.

${ }^{\star} P<0.05$, compared with cells not cocultured with lymphocytes 

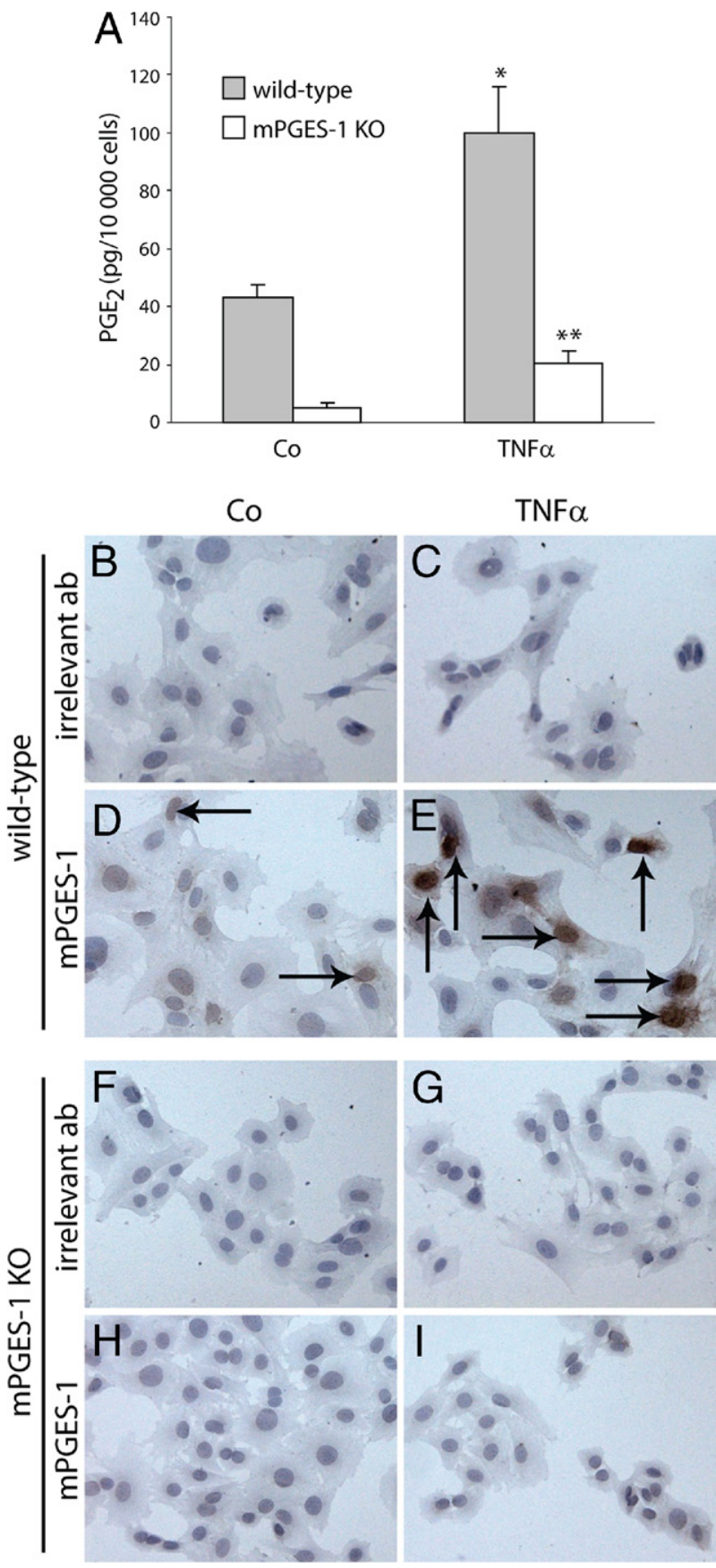

Figure 8. Production of $\mathrm{PGE}_{2}$ and expression of $\mathrm{mPGES}-1$ in gingival fibroblasts isolated from mPGES-1 knockout (KO) mice and wild-type mice. The cells were treated either with medium alone (control) or with TNF- $\alpha$ (20 $\mathrm{ng} / \mathrm{mL}$ ). A: In vitro production of $\mathrm{PGE}_{2}$ in gingival fibroblasts isolated from mPGES-1 KO and wild-type mice. ${ }^{*} P<0.05$ compared with wild-type control cells not treated with TNF- $\alpha$; ${ }^{* *} P<0.05$ compared with mPGES-1 KO control cells not treated with TNF- $\alpha$. D and $\mathbf{H}$ : Expression of mPGES-1 in untreated gingival fibroblasts (control cells, Co) derived from wild-type mice and mPGES KO mice, respectively, as detected by immunohistochemistry. $\mathbf{E}$ and I: Expression of mPGES-1 in TNF- $\alpha$ stimulated gingival fibroblasts derived from wild-type mice and mPGES-1 KO mice, respectively. B, C, F, and G: Immunohistochemistry staining of the cells with irrelevant polyclonal antibodies (irrelevant ab). Intracellular positive staining is revealed as darkbrown deposit (arrows). Original magnification, $\times 500$ (all images).

TNF- $\alpha$ and IL- $1 \beta$ were used as inflammatory stimuli, because both have been reported to stimulate $\mathrm{PGE}_{2}$ production in different cell types, and have been implicated in the pathogenesis of chronic inflammatory diseases, including periodontitis. ${ }^{48-51}$ Furthermore, because CD $45^{+}$cells were present in the tissues, we also investigated the effect of CD45-expressing cells (lymphocytes ${ }^{52}$ ) on the production of PGE 2 and expression of mPGES-1 and COX-2 in the adherent cells, using cocultures.

We first investigated the most ubiquitous cells in gingival connective tissue, gingival fibroblasts, which were positively stained for mPGES-1, mPGES-2, cPGES, and COX-2 in immunohistochemical analysis of gingival tissue. We found that all three PGE synthases were also expressed in cultured primary gingival fibroblasts. Furthermore, in accord with our previous findings, the inducible enzymes mPGES-1 and COX-2 were up-regulated by the inflammatory cytokines TNF- $\alpha$ and $\mathrm{IL}-1 \beta$ in parallel with $\mathrm{PGE}_{2}$ production. ${ }^{32,53}$ The increased $\mathrm{PGE}_{2}$ production via enhanced expression of mPGES-1 and COX-2 observed in gingival fibroblasts is in accord with data on synovial, orbital, and gastric fibroblasts, as well as with our previous data on gingival fibroblasts. ${ }^{48,54-56}$ The present findings that gingival fibroblasts express increased amounts of mPGES-1 and COX-2, leading to enhanced $\mathrm{PGE}_{2}$ production, together with reports on the significance of fibroblasts in chronic inflammatory conditions, highlight the importance of these cells in contributing to the pathogenesis of periodontitis. ${ }^{57}$

The in vitro experiments using HUVECs as a model system revealed a basal expression of PGE synthases and COX-2, accompanied by $\mathrm{PGE}_{2}$ production. Neither mPGES-1 nor mPGES-2 or CPGES were affected by cytokine treatment, in contrast to COX-2 increasing in parallel with $\mathrm{PGE}_{2}$ production after $\mathrm{TNF}-\alpha$ stimulation. Our results from this cell model system suggest that the inflammationinduced up-regulation of $\mathrm{PGE}_{2}$ production in HUVECs may be dependent on increased expression of COX-2, rather than mPGES-1, as has also been reported for TNF- $\alpha$-increased COX-2 expression in primary HUVECs. ${ }^{58}$ Moreover, neither mPGES-1 nor COX-2 expression, nor PGE 2 production, increased in response to $\mathrm{IL}-1 \beta$ in a hybrid cell line between HUVECs and A549 cells, which is also in accord with our results. ${ }^{59}$

Because vessels include both endothelial and smooth muscle cells, we also studied the expression of PGE synthases in relation to $\mathrm{PGE}_{2}$ production in cultures of smooth muscle cells, using HASM cells as an in vitro model system. We have shown here that the expression of mPGES-1 and COX-2, as well as $\mathrm{PGE}_{2}$ production, increased in response to TNF- $\alpha$ and IL- $1 \beta$ stimulation in HASM cells. The expression of PGE synthases has not been previously reported in HASM cells, although COX-2 expression and $\mathrm{PGE}_{2}$ production have been shown to be increased by IL-1 $\beta$, which is in accord with our results. ${ }^{60}$ Similar to the present results, the expression of PGE synthases and the up-regulation of MPGES-1, COX-2, and $\mathrm{PGE}_{2}$ in response to IL- $1 \beta$ and TNF- $\alpha$ have also been demonstrated in primary human vascular smooth muscle cells. $^{61,62}$ In one of those studies, ${ }^{62}$ the authors also demonstrated the lack of mPGES-1 induction in HUVEC cells, which is in accord with our results obtained from HUVEC cells. The substantial increase in expression of $P G E$ synthases and subsequently increased $\mathrm{PGE}_{2}$ pro- 
duction observed in smooth muscle cells in the present study highlights these cells as potentially an important cell type contributing to the elevated levels of $\mathrm{PGE}_{2}$ in gingival tissue.

In connective tissue, we showed that immune cells were positively stained for PGE synthases and COX-2. Monocytic cells have been previously studied in this regard, demonstrating that TNF- $\alpha$ and IL- $1 \beta$ increase expression of mPGES-1 and COX-2 as well as $\mathrm{PGE}_{2}$ production in the monocytic cell line THP- $1 .{ }^{63}$ Mast cells, on the other hand, constitute a part of the inflammatory response that has been poorly studied in regard to the expression of PGE synthases and $\mathrm{PGE}_{2}$ production. Cultured human mast cells revealed a basal expression of PGE synthases and COX-2, as well as a basal production of $\mathrm{PGE}_{2}$, but no increase in response to TNF- $\alpha$ or IL-1 $\beta$. Nonetheless, the basal $\mathrm{PGE}_{2}$ production of these cells may still contribute to enhanced total $\mathrm{PGE}_{2}$ production through an additive effect, because an increased number of mast cells has been reported in inflamed gingival tissue, compared with healthy gingival tissue. ${ }^{64,65}$ To our knowledge, there are a very limited number of studies investigating the expression of $\mathrm{PGE}_{2}$-synthesizing enzymes or $\mathrm{PGE}_{2}$ production in mast cells; however, COX-2 expression and $\mathrm{PGE}_{2}$ production are increased by antigen stimulation and by the phospholipase $A_{2}$ activator melittin, respectively. ${ }^{66,67}$

In addition to the $\mathrm{PGE}_{2}$-synthesizing enzymes, the cytokine IL-1 $\beta$, apparently localized to $\mathrm{CD} 45^{+}$cells, was positively stained in the gingival tissue biopsies of patients with periodontitis. Our results demonstrating that the expression of mPGES-1 and COX-2 increased in fibroblasts and smooth muscle cells in response to the cytokines indicate that $\mathrm{CD} 45^{+}$cells, by producing cytokines such as $\mathrm{IL}-1 \beta,{ }^{68}$ may regulate the production of $\mathrm{PGE}_{2}$ in inflamed gingival tissue. These results are also in accord with our previous findings that fibroblasts cocultured with CD45-expressing lymphocytes ${ }^{52}$ increased their COX-2 expression as well as $\mathrm{PGE}_{2}$ production, ${ }^{40}$ suggesting a regulatory interplay among these cells contributing to the up-regulation of $\mathrm{PGE}_{2}$ synthesis. The regulation of $\mathrm{PGE}_{2}$ production may also include a network of signal transduction pathways within the cells involved. For instance, the $\mathrm{c}$-jun $\mathrm{N}$-terminal protein kinase and nuclear factor $\kappa \mathrm{B}$ signaling pathways are reported to play an important role in the regulation of mPGES- 1 and COX-2 expression in response to the cytokines IL-1 $\beta$ and TNF- $\alpha$ in gingival fibroblasts. ${ }^{69-71}$ These intracellular pathways have also been shown to play a significant role in smooth muscle cells, mast cells, and endothelial cells. ${ }^{72-74}$ Hence, the expression of $\mathrm{PGE}_{2}$-synthesizing enzymes is most likely regulated by a complex network of cytokines and signal transduction pathways, as well as by cross-talk interactions among cells.

Whereas the mPGES-1 isoform has been more extensively studied, the roles of the PGE synthase isoforms mPGES-2 and cPGES have been debated. It has been suggested that mPGES-2 may substitute for mPGES-1 in case of nonfunctioning mPGES-1 ${ }^{75}$ However, no up-regulation of mPGES-2 expression was observed under inflammatory conditions in murine mPGES-1 null fibroblasts or macrophages. ${ }^{76,77}$ Moreover, we have previously reported that neither small interfering RNA (siRNA) knockdown nor chemical mPGES-1 inhibition affects the expression of CPGES or mPGES-2 in human gingival fibroblasts. ${ }^{31}$ Our experiments with mPGES-1 null gingival fibroblasts clearly demonstrated that mPGES- 1 is important for basal production of $\mathrm{PGE}_{2}$ and critical for $\mathrm{PGE}_{2}$ production under inflammatory condition. The observed low but significant $\mathrm{PGE}_{2}$ production in TNF- $\alpha$-induced mPGES-1 null gingival fibroblasts might be due to COX-2 induction, as has been demonstrated for mouse mPGES-1 null macrophages. ${ }^{76}$

Numerous cell types present in the gingival connective tissue may contribute to the increased $\mathrm{PGE}_{2}$ production in gingival tissue and gingival fluid from patients with periodontitis. The cell types included in the present in vitro studies were shown to contribute to $\mathrm{PGE}_{2}$ synthesis; however, the levels of $\mathrm{PGE}_{2}$ released per cell varied among cell types (Figures 4-7). Of the cells included in the in vitro analyses, gingival fibroblasts and smooth muscle cells exhibited a higher basal $\mathrm{PGE}_{2}$ production, and these two cell types also considerably increased $\mathrm{PGE}_{2}$ production in response to cytokines, via the inflammationinduced enzymes mPGES-1 and COX-2. HUVECs and mast cells produced lower amounts of $\mathrm{PGE}_{2}$, which in HUVECs was increased only in response to TNF- $\alpha$, whereas $\mathrm{PGE}_{2}$ production in mast cells was not stimulated by the cytokines. Our results suggest that, of the cells tested, the most prominent cellular sources of inflammation-induced $\mathrm{PGE}_{2}$ are fibroblasts and smooth muscle cells. Furthermore, both endothelial cells (via COX-2) and mast cells may contribute to elevated $\mathrm{PGE}_{2}$ levels. Nonetheless, one must keep in mind that the in vitro findings are not directly transferrable to the in vivo situation (an indication of the need for further studies).

In conclusion, the results presented here suggest that inflammation-induced $\mathrm{PGE}_{2}$ production is regulated by mPGES-1 and COX-2 in fibroblasts and smooth muscle cells, which may contribute to the increased $\mathrm{PGE}_{2}$ levels in the inflamed gingival tissue of patients with periodontitis. The present work contributes an initial step toward revealing the cellular source and regulation of increased $\mathrm{PGE}_{2}$ in the inflammatory disease periodontitis.

\section{Acknowledgments}

We thank Dr. Per-Rune Wretling, D.D.S., for contributing to the collection of gingival biopsies, Ms. Caroline Nguyen for valuable help with cell cultures, Mr. Pierre Georgsson for contributing to illustrations, and Mr. Hernan Concha Quezada for help with flow cytometric analyses.

\section{References}

1. Pihlstrom BL, Michalowicz BS, Johnson NW: Periodontal diseases Lancet 2005, 366:1809-1820

2. Saegusa M, Murakami M, Nakatani Y, Yamakawa K, Katagiri M Matsuda K, Nakamura K, Kudo I, Kawaguchi H: Contribution of membrane-associated prostaglandin E2 synthase to bone resorption. J Cell Physiol 2003, 197:348-356 
3. Dewhirst FE, Moss DE, Offenbacher S, Goodson JM: Levels of prostaglandin E2, thromboxane, and prostacyclin in periodontal tissues. $J$ Periodontal Res 1983, 18:156-163

4. Preshaw PM, Heasman PA: Prostaglandin E2 concentrations in gingival crevicular fluid: observations in untreated chronic periodontitis. J Clin Periodontol 2002, 29:15-20

5. Tsai CC, Hong YC, Chen CC, Wu YM: Measurement of prostaglandin E2 and leukotriene B4 in the gingival crevicular fluid. J Dent 1998 , 26:97-103

6. Salvi GE, Lang NP: The effects of non-steroidal anti-inflammatory drugs (selective and non-selective) on the treatment of periodontal diseases. Curr Pharm Des 2005, 11:1757-1769

7. Williams RC, Jeffcoat MK, Howell TH, Rolla A, Stubbs D, Teoh KW, Reddy MS, Goldhaber P: Altering the progression of human alveolar bone loss with the non-steroidal anti-inflammatory drug flurbiprofen. $J$ Periodontol 1989, 60:485-490

8. Yen CA, Damoulis PD, Stark PC, Hibberd PL, Singh M, Papas AS: The effect of a selective cyclooxygenase-2 inhibitor (celecoxib) on chronic periodontitis. J Periodontol 2008, 79:104-113

9. Inada M, Matsumoto C, Uematsu S, Akira S, Miyaura C: Membranebound prostaglandin $\mathrm{E}$ synthase-1-mediated prostaglandin E2 production by osteoblast plays a critical role in lipopolysaccharideinduced bone loss associated with inflammation. J Immunol 2006 , $177: 1879-1885$

10. Kaneko H, Mehrotra M, Alander C, Lerner U, Pilbeam C, Raisz L: Effects of prostaglandin E2 and lipopolysaccharide on osteoclastogenesis in RAW 264.7 cells. Prostaglandins Leukot Essent Fatty Acids 2007, 77:181-186

11. Bingham $\mathrm{CO} 3 \mathrm{rd}$, Austen KF: Phospholipase A2 enzymes in eicosanoid generation. Proc Assoc Am Physicians 1999, 111:516-524

12. Needleman P: Characterization of the reaction sequence involved in phospholipid labeling and deacylation and prostaglandin synthesis and actions. J Allergy Clin Immunol 1978, 62:96-102

13. Smith WL, Song I: The enzymology of prostaglandin endoperoxide $H$ synthases-1 and -2. Prostaglandins Other Lipid Mediat 2002, 68-69: $115-128$

14. Jakobsson PJ, Thorén S, Morgenstern R, Samuelsson B: Identification of human prostaglandin E synthase: a microsomal, glutathionedependent, inducible enzyme, constituting a potential novel drug target. Proc Natl Acad Sci USA 1999, 96:7220-7225

15. Watanabe K, Kurihara K, Tokunaga Y, Hayaishi O: Two types of microsomal prostaglandin $\mathrm{E}$ synthase: glutathione-dependent and -independent prostaglandin E synthases. Biochem Biophys Res Commun 1997, 235:148-152

16. Murakami M, Kudo I: Recent advances in molecular biology and physiology of the prostaglandin E2-biosynthetic pathway. Prog Lipid Res 2004, 43:3-35

17. Murakami M, Nakatani $Y$, Tanioka T, Kudo I: Prostaglandin E synthase. Prostaglandins Other Lipid Mediat 2002, 68-69:383-399

18. Park JY, Pillinger MH, Abramson SB: Prostaglandin E2 synthesis and secretion: the role of PGE2 synthases. Clin Immunol 2006, 119:229-240

19. Rao P, Knaus EE: Evolution of nonsteroidal anti-inflammatory drugs (NSAIDs): cyclooxygenase (COX) inhibition and beyond. J Pharm Pharm Sci 2008, 11:81s-110s

20. Watanabe K, Kurihara K, Suzuki T: Purification and characterization of membrane-bound prostaglandin E synthase from bovine heart. Biochim Biophys Acta 1999, 1439:406-414

21. Tanioka T, Nakatani $Y$, Semmyo N, Murakami M, Kudo I: Molecular identification of cytosolic prostaglandin E2 synthase that is functionally coupled with cyclooxygenase-1 in immediate prostaglandin E2 biosynthesis. J Biol Chem 2000, 275:32775-32782

22. Jania LA, Chandrasekharan S, Backlund MG, Foley NA, Snouwaert J, Wang IM, Clark P, Audoly LP, Koller BH: Microsomal prostaglandin E synthase-2 is not essential for in vivo prostaglandin E2 biosynthesis. Prostaglandins Other Lipid Mediat 2009, 88:73-81

23. Murakami M, Kudo I: Prostaglandin E synthase: a novel drug target for inflammation and cancer. Curr Pharm Des 2006, 12:943-954

24. Tanikawa N, Ohmiya Y, Ohkubo H, Hashimoto K, Kangawa K, Kojima M, Ito S, Watanabe K: Identification and characterization of a novel type of membrane-associated prostaglandin E synthase. Biochem Biophys Res Commun 2002, 291:884-889
25. Siegel B, Weihe E, Bette M, Nusing RM, Flores-de-Jacoby L, Mengel $R$ : The effect of age on prostaglandin-synthesizing enzymes in the development of gingivitis. J Periodontal Res 2007, 42:259-266

26. Beikler T, Peters U, Prior K, Eisenacher M, Flemmig TF: Gene expression in periodontal tissues following treatment. BMC Med Genomics 2008, 1:30

27. Morton RS, Dongari-Bagtzoglou Al: Cyclooxygenase-2 is upregulated in inflamed gingival tissues. J Periodontol 2001, 72:461-469

28. Zhang F, Engebretson SP, Morton RS, Cavanaugh PF Jr, Subbaramaiah K, Dannenberg AJ: The overexpression of cyclo-oxygenase-2 in chronic periodontitis. J Am Dent Assoc 2003, 134:861-867

29. Savage A, Eaton KA, Moles DR, Needleman I: A systematic review of definitions of periodontitis and methods that have been used to identify this disease. J Clin Periodontol 2009, 36:458-467

30. Korotkova M, Helmers SB, Loell I, Alexanderson H, Grundtman C, Dorph C, Lundberg IE, Jakobsson PJ: Effects of immunosuppressive treatment on microsomal prostaglandin E synthase 1 and cyclooxygenases expression in muscle tissue of patients with polymyositis or dermatomyositis. Ann Rheum Dis 2008, 67:1596-1602

31. Båge $T$, Modéer $T$, Kawakami T, Quezada HC, Yucel-Lindberg $T$ : Regulation of prostaglandin E synthases: effects of siRNA-mediated inhibition of microsomal prostaglandin E synthase-1. Biochim Biophys Acta 2007, 1773:1589-1598

32. Yucel-Lindberg T, Olsson T, Kawakami T: Signal pathways involved in the regulation of prostaglandin E synthase-1 in human gingival fibroblasts. Cell Signal 2006, 18:2131-2142

33. Trebino CE, Stock JL, Gibbons CP, Naiman BM, Wachtmann TS, Umland JP, Pandher K, Lapointe JM, Saha S, Roach ML, Carter D, Thomas NA, Durtschi BA, McNeish JD, Hambor JE, Jakobsson PJ, Carty TJ, Perez JR, Audoly LP: Impaired inflammatory and pain responses in mice lacking an inducible prostaglandin E synthase. Proc Natl Acad Sci USA 2003, 100:9044-9049

34. Ulfgren AK, Lindblad S, Klareskog L, Andersson J, Andersson U: Detection of cytokine producing cells in the synovial membrane from patients with rheumatoid arthritis. Ann Rheum Dis 1995, 54:654-661

35. Westman M, Korotkova M, af Klint E, Stark A, Audoly LP, Klareskog L, Ulfgren AK, Jakobsson PJ: Expression of microsomal prostaglandin $E$ synthase 1 in rheumatoid arthritis synovium. Arthritis Rheum 2004 50:1774-1780

36. Pang L, Knox AJ: PGE2 release by bradykinin in human airway smooth muscle cells: involvement of cyclooxygenase-2 induction. Am J Physiol 1997, 273:L1132-L1140

37. Butterfield JH, Weiler D, Dewald G, Gleich GJ: Establishment of an immature mast cell line from a patient with mast cell leukemia. Leuk Res 1988, 12:345-355

38. Nilsson G, Butterfield JH, Nilsson K, Siegbahn A: Stem cell factor is a chemotactic factor for human mast cells. J Immunol 1994, 153:37173723

39. Sundström M, Vliagoftis $H$, Karlberg $P$, Butterfield JH, Nilsson $K$, Metcalfe DD, Nilsson G: Functional and phenotypic studies of two variants of a human mast cell line with a distinct set of mutations in the c-kit proto-oncogene. Immunology 2003, 108:89-97

40. Yucel-Lindberg T, Brunius G, Wondimu B, Anduren I, Modéer T: Enhanced cyclooxygenase-2 mRNA expression in human gingival fibroblasts induced by cell contact with human lymphocytes. Eur J Oral Sci 2001, 109:187-192

41. Gentleman RC, Carey VJ, Bates DM, Bolstad B, Dettling M, Dudoit S, Ellis B, Gautier L, Ge Y, Gentry J, Hornik K, Hothorn T, Huber W, lacus S, Irizarry R, Leisch F, Li C, Maechler M, Rossini AJ, Sawitzki G, Smith C, Smyth G, Tierney L, Yang JY, Zhang J: Bioconductor: open software development for computational biology and bioinformatics. Genome Biol 2004, 5:R80

42. Seguier S, Godeau G, Brousse N: Collagen fibers and inflammatory cells in healthy and diseased human gingival tissues: a comparative and quantitative study by immunohistochemistry and automated image analysis. J Periodontol 2000, 71:1079-1085

43. Lo YJ, Liu CM, Wong MY, Hou LT, Chang WK: Interleukin 1betasecreting cells in inflamed gingival tissue of adult periodontitis patients. Cytokine 1999, 11:626-633

44. Engblom D, Saha S, Engström L, Westman M, Audoly LP, Jakobsson $\mathrm{PJ}$, Blomqvist A: Microsomal prostaglandin E synthase-1 is the central switch during immune-induced pyresis. Nat Neurosci 2003, 6:1137-1138 
45. Gudis K, Tatsuguchi A, Wada K, Futagami S, Nagata K, Hiratsuka T, Shinji Y, Miyake K, Tsukui T, Fukuda Y, Sakamoto C: Microsomal prostaglandin E synthase (mPGES)-1, mPGES-2 and cytosolic PGES expression in human gastritis and gastric ulcer tissue. Lab Invest 2005, 85:225-236

46. Nakashima K, Roehrich N, Cimasoni G: Osteocalcin, prostaglandin E2 and alkaline phosphatase in gingival crevicular fluid: their relations to periodontal status. J Clin Periodontol 1994, 21:327-333

47. Offenbacher S, Heasman PA, Collins JG: Modulation of host PGE2 secretion as a determinant of periodontal disease expression. J Periodontol 1993, 64(5 Suppl):432-444

48. Han R, Tsui S, Smith TJ: Up-regulation of prostaglandin E2 synthesis by interleukin-1beta in human orbital fibroblasts involves coordinate induction of prostaglandin-endoperoxide $\mathrm{H}$ synthase-2 and glutathione-dependent prostaglandin E2 synthase expression. J Biol Chem 2002, 277:16355-16364

49. Petrovic N, Knight DA, Bomalaski JS, Thompson PJ, Misso NL: Concomitant activation of extracellular signal-regulated kinase and induction of COX-2 stimulates maximum prostaglandin E2 synthesis in human airway epithelial cells. Prostaglandins Other Lipid Mediat 2006, 81:126-135

50. Ransjö M, Marklund M, Persson M, Lerner UH: Synergistic interactions of bradykinin, thrombin, interleukin 1 and tumor necrosis factor on prostanoid biosynthesis in human periodontal-ligament cells. Arch Oral Biol 1998, 43:253-260

51. Graves DT, Cochran D: The contribution of interleukin-1 and tumor necrosis factor to periodontal tissue destruction. J Periodontol 2003, 74:391-401

52. Saunders $A E$, Johnson $P$ : Modulation of immune cell signalling by the leukocyte common tyrosine phosphatase, CD45. Cell Signal 2010, 22:339-348

53. Yucel-Lindberg T, Hallstrom T, Kats A, Mustafa M, Modéer T: Induction of microsomal prostaglandin $E$ synthase-1 in human gingival fibroblasts. Inflammation 2004, 28:89-95

54. Gitter BD, Labus JM, Lees SL, Scheetz ME: Characteristics of human synovial fibroblast activation by IL-1 beta and TNF alpha. Immunology 1989, 66:196-200

55. Shinji Y, Tsukui T, Tatsuguchi A, Shinoki K, Kusunoki M, Suzuki K, Hiratsuka T, Wada K, Futagami S, Miyake K, Gudis K, Sakamoto C: Induced microsomal PGE synthase-1 is involved in cyclooxygenase2-dependent PGE2 production in gastric fibroblasts. Am J Physiol Gastrointest Liver Physiol 2005, 288:G308-G315

56. Yao H, Zhou J, Li D, Wu N, Bader A, Höxtermann S, Altmeyer P, Brockmeyer NH: FK506 enhances triptolide-induced down-regulation of cyclooxygenase-2, inducible nitric oxide synthase as well as their products PGE2 and NO in TNF-alpha-stimulated synovial fibroblasts from rheumatoid arthritic patients. Eur J Med Res 2005, 10:110-116

57. Flavell SJ, Hou TZ, Lax S, Filer AD, Salmon M, Buckley CD: Fibroblasts as novel therapeutic targets in chronic inflammation. $\mathrm{Br} J$ Pharmacol 2008, 153 Suppl 1:S241-246

58. Kuldo JM, Westra J, Asgeirsdóttir SA, Kok RJ, Oosterhuis K, Rots MG Schouten JP, Limburg PC, Molema G: Differential effects of NF\{kappa\}B and p38 MAPK inhibitors and combinations thereof on TNF-\{alpha\}- and IL-1 1 beta\}-induced proinflammatory status of endothelial cells in vitro. Am J Physiol Cell Physiol 2005, 289:C1229C1239

59. Olszanecki R, Gebska A, Korbut R: Production of prostacyclin and prostaglandin E2 in resting and IL-1beta-stimulated A549, HUVEC and hybrid EA.HY 926 cells. J Physiol Pharmacol 2006, 57:649-660

60. Moore PE, Lahiri T, Laporte JD, Church T, Panettieri RA Jr, Shore SA: Selected contribution: synergism between TNF-alpha and IL-1 beta in airway smooth muscle cells: implications for beta-adrenergic responsiveness. J Appl Physiol 2001, 91:1467-1474

61. Camacho M, Gerboles E, Escudero JR, Anton R, Garcia-Moll X, Vila $\mathrm{L}$ : Microsomal prostaglandin $\mathrm{E}$ synthase-1, which is not coupled to a particular cyclooxygenase isoenzyme, is essential for prostaglandin $\mathrm{E}(2)$ biosynthesis in vascular smooth muscle cells. J Thromb Haemost 2007, 5:1411-1419
62. Soler M, Camacho M, Escudero JR, Iñiguez MA, Vila L: Human vascular smooth muscle cells but not endothelial cells express prostaglandin E synthase. Circ Res 2000, 87:504-507

63. Gómez-Hernández A, Sánchez-Galán E, Martín-Ventura JL, Vidal C, Blanco-Colio LM, Ortego M, Vega M, Serrano J, Ortega L, Hernández G, Tunón J, Egido J: Atorvastatin reduces the expression of prostaglandin E2 receptors in human carotid atherosclerotic plaques and monocytic cells: potential implications for plaque stabilization. J Cardiovasc Pharmacol 2006, 47:60-69

64. Gunhan M, Bostanci H, Gunhan O, Demiriz M: Mast cells in periodontal disease. Ann Dent 1991, 50:25-29

65. Steinsvoll S, Helgeland K, Schenck K: Mast cells-a role in periodontal diseases? J Clin Periodontol 2004, 31:413-419

66. Hundley TR, Prasad AR, Beaven MA: Elevated levels of cyclooxygenase-2 in antigen-stimulated mast cells is associated with minimal activation of p38 mitogen-activated protein kinase. J Immunol 2001 , 167:1629-1636

67. Lee JH, Lee JY, Kang HS, Jeong CH, Moon H, Whang WK, Kim CJ, Sim SS: The effect of acteoside on histamine release and arachidonic acid release in RBL-2H3 mast cells. Arch Pharm Res 2006 , 29:508-513

68. Marsh CB, Lowe MP, Rovin BH, Parker JM, Liao Z, Knoell DL, Wewers MD: Lymphocytes produce IL-1beta in response to Fcgamma receptor cross-linking: effects on parenchymal cell IL-8 release. J Immunol 1998, 160:3942-3948

69. Båge T, Lindberg J, Lundeberg J, Modéer T, Yucel-Lindberg T: Signal pathways JNK and NF-kappaB, identified by global gene expression profiling, are involved in regulation of TNFalpha-induced mPGES-1 and COX-2 expression in gingival fibroblasts. BMC Genomics 2010, 11:241

70. Kida Y, Kobayashi M, Suzuki T, Takeshita A, Okamatsu Y, Hanazawa S, Yasui T, Hasegawa K: Interleukin-1 stimulates cytokines, prostaglandin E2 and matrix metalloproteinase-1 production via activation of MAPK/AP-1 and NF-kappaB in human gingival fibroblasts. Cytokine 2005, 29:159-168

71. Nakao S, Inoue D: Involvement of protein kinase C in IL-1betainduced expression of cyclooxygenase-2 in human gingival fibroblasts. J Oral Sci 2009, 51:417-423

72. Ho FM, Kang HC, Lee ST, Chao Y, Chen YC, Huang LJ, Lin WW: The anti-inflammatory actions of LCY-2-CHO, a carbazole analogue, in vascular smooth muscle cells. Biochem Pharmacol 2007, 74:298-308

73. Kim SJ, Jeong HJ, Choi IY, Lee KM, Park RK, Hong SH, Kim HM Cyclooxygenase-2 inhibitor SC-236 [4-[5-(4-chlorophenyl)-3-(trifluoromethyl)-1-pyrazol-1-I] benzenesulfonamide] suppresses nuclear factor-kappaB activation and phosphorylation of p38 mitogen-activated protein kinase, extracellular signal-regulated kinase, and c-Jun $\mathrm{N}$-terminal kinase in human mast cell line cells. J Pharmacol Exp Ther 2005, 314:27-34

74. Kim YS, Ahn Y, Hong MH, Kim KH, Park HW, Hong YJ, Kim JH, Kim W, Jeong MH, Cho JG, Park JC, Kang JC: Rosuvastatin suppresses the inflammatory responses through inhibition of C-Jun N-termina kinase and Nuclear Factor-kappaB in endothelial cells. J Cardiovasc Pharmacol 2007, 49:376-383

75. Kubota K, Kubota T, Kamei D, Murakami M, Kudo I, Aso T, Morita I: Change in prostaglandin E synthases (PGESs) in microsomal PGES-1 knockout mice in a preterm delivery model. J Endocrinol 2005, 187: 339-345

76. Kamei D, Yamakawa K, Takegoshi Y, Mikami-Nakanishi M, Nakatani Y, Oh-Ishi S, Yasui H, Azuma Y, Hirasawa N, Ohuchi K, Kawaguchi H, Ishikawa Y, Ishii T, Uematsu S, Akira S, Murakami M, Kudo I: Reduced pain hypersensitivity and inflammation in mice lacking microsomal prostaglandin E synthase-1. J Biol Chem 2004, 279:33684-33695

77. Kapoor M, Kojima F, Yang L, Crofford LJ: Sequential induction of proand anti-inflammatory prostaglandins and peroxisome proliferatorsactivated receptor-gamma during normal wound healing: a time course study. Prostaglandins Leukot Essent Fatty Acids 2007, 76: 103-112 